University of Louisville

ThinkIR: The University of Louisville's Institutional Repository

Electronic Theses and Dissertations

$6-1948$

\title{
A comparative study of part-time and non-working students at Louisville Male High School.
}

William L. Walters

University of Louisville

Follow this and additional works at: https://ir.library.louisville.edu/etd

Part of the Education Commons

\section{Recommended Citation}

Walters, William L., "A comparative study of part-time and non-working students at Louisville Male High School." (1948). Electronic Theses and Dissertations. Paper 2184.

https://doi.org/10.18297/etd/2184

This Master's Thesis is brought to you for free and open access by ThinkIR: The University of Louisville's Institutional Repository. It has been accepted for inclusion in Electronic Theses and Dissertations by an authorized administrator of ThinkIR: The University of Louisville's Institutional Repository. This title appears here courtesy of the author, who has retained all other copyrights. For more information, please contact thinkir@louisville.edu. 


\author{
$-3+15$ \\ A COMPARATIVE STUDY \\ OF \\ PART-TIME AND WOI-WOPKING \\ STUDENTS \\ AT \\ LOUISVILLE MALE HIGH SCHOOL
}

William L. Walters University of Louisville Liberal Arts College June 1948

Submitted in Partial Fulfillment of the Requirements for A Naster of Arts Dogree 


\section{NAME OF STUDENT: William L. Walters \\ TITLE OF THESIS: A COMPARATIVE STUDY OF PART- TIME AND NON-WORKING STUDENTS AT LOUIS- MALE HIGH SCHOOL APPROVED BY A READING COMDITTEE COMPOSED OF THE FOLLOWING MEMBERS :}

ADVISOR: $\frac{\text { Hilda Threlkeld }}{\frac{\text { W. C. Mallalieu }}{\text { J. J. Oppenheimer }}}$

ii. 


\section{ACKNOWLEDGMENT}

Invaluablo assistance was received by the writer in writing this thesis on A Study of Part-Time and Non-Working Students at Louisville Male High School for which he now makes ackmowledgment; to Dr. Hilda Threlkeld, Dean of Women, University of Louisville and Dr. J. J. Oppenheimer, Dean of the Liberal Arts School, University of Louisville for inspiration and guidance in making the study; to Mr. W. S. Milburn, Prinolpal, Louisville Male High Sohool, for permission to use that school in the study; to Mr. A. E. Kalmer, Dean, Louisville Male High School, for friendly assistance in obtaining necossary information and data on students in that school for the study; to Mrs. Mary Hodge Cox for aid on sentence structure and grammar used in writing up the study; and to Mr. Raymond Walters, the writer's brother, and Miss Glenna Rae Jetter for assistance in compiling information and data from the questionnatro used in the study. William L. Walters 
CONTENTS

CHAPTER

PAGE

A. The Part-Time Working Student and the High

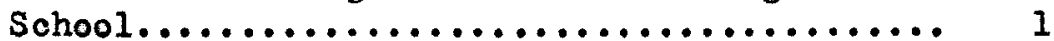

B. Statement of the Problem.................. 2

C. Interests Motivating the Study .............. 3

D. Louisville Male High School ................. 4

1. Historical Information ................ 5

2. School Philosophy .................. 6

3. Enrollment........................ 7

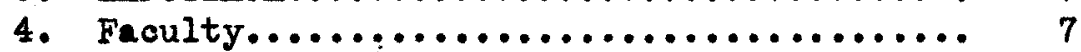

E. Method of Obtaining ind Compiling Data......... 8

F. Organization of this Thesis ................ 10

II. BACKGROUND $\ldots \ldots \ldots \ldots \ldots \ldots \ldots \ldots \ldots \ldots \ldots \ldots \ldots \ldots \ldots \ldots \ldots \ldots \ldots \ldots \ldots$

A. Introduction .......................... 11

B. Work-Experience Definod ................... 11

C. Some Areas of Need to Which Work-Experience

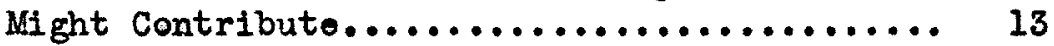

1. Indoctrination in the Democratic Way of Life ........................ 13

2. Bridging the Gap Between School and Employment .................... 16

D. The Responsibility of Providing Werk-Experience 20

1. The Sohool and the Responsibility of

Providing Work-Experience .......... 22

2. A Combined Responsibility ............. 24

E. Rocipients of Work-Experience ................ 26

F. Findings and Conclusions of Significant Studies on Organized Work-Experience Programs ....... 28

1. A Study Made by the National Child Labor

Comittee ...................... 29

a. Objeotives of a Work-Experience

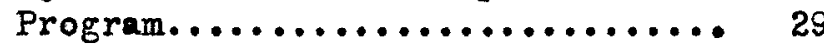

b. Evaluation of Work-Experience Programs ................... 30

c. Constructive Values of Part-Time Work Prograns ................ 30

d. Students for Whom Participation in a Part-Time Work Program May Be Valuable 
- Selection of Student Participants

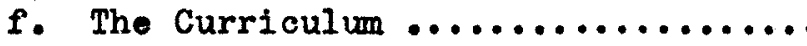

2. A Joint-Study of the J.S. Office of

Education and the Children's Bureau of the

U.S. Department of Labor ...............

a. Purposes of School-and-work

Programs .................... 33

b. Types of Arrangements for Releasing Students for Work ............. 33

c. Good Features of School-and-Work Programs .................... 34

d. Bad Features of School-and-Work Programs ................... 34

- Conclusions of the U.S. Office of Education on School-and-Work

Programs ...................

1) Selection of Students Who Will Profit from Participation .... 35

2) Choice of Suitable Jobs ..... 36

3) Operational Controls of the Program ................. 36

4) Pormanent Values of the Program 36

G. Summary

$\ldots \ldots \ldots \ldots \ldots \ldots \ldots \ldots \ldots \ldots \ldots \ldots \ldots \ldots$

III. THE WORKING STUDENT AT MALE HIGH AND HIS JOB ....... 39

A. Number and Por Cent of Working Students ........ 39

B. Why Students Work ........................ 40

C. Ages of Working Students ................... 43

D. Nature of Bmployment ...................... 44

1. Types of Jobs ...................... 44

2. Hours on the Job ...................... 48

3. Salary ............................. 49

E. Attitudes Toward Work and Jobs ............... 51

F. Effects of Part-Time Work Upon School Work ...... 53

$G$. The School and the Working Student ........... 55

H. Summary ond Conclusions ................... 57

IV. THE NON-WORKING STUDENT AT MALE HIGH . ............ 64

A. Number and Per-Cent of Non-Working Students ..... 64

B. Ages of Non-Working Students ................ 65

C. Why Students Do Not Participate in Part-Time Work 66

D. Opinions of Part-Time Work ................... 68

1. Advisability of High School Students

Participating in Part-Time Work ....... 69 
2. Dosires of Non-Working Students for a

Part-Time Job .................... 70

E. Sumary ............................... 71

V. A COMPARISON OF WORKING AND NON-WOKKING STUDENTS .... 74

A. Ages ................................... 74

B. Scholestic Attainment ................... 76

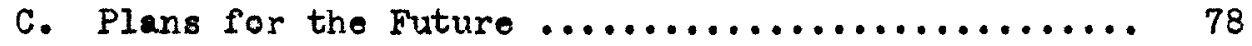

1. Plans for Further Edueation ........... 78

2. Vocational Plans .................... 81

D. Views on Educational Value of Part-Time Work .... 83

E. Views on Vocational Guidance ................. 84

1. The Need for More Vocational Guidance ..... 85

2. Relation of Vocational Guidance to

Traditional Subject Matter .......... 85

3. The Need for A Job Placement Service ..... 86

F. How Students Use Their Income ................ 88

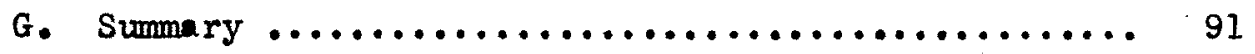

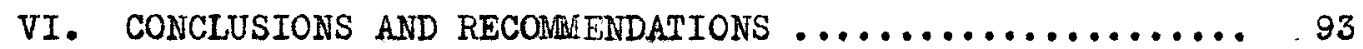

\section{APPENDICES}

I. QUESTIONNAIRE USED IN THIS STUDY ............... 101

II. WORK PERMIT USED AT MALE HIGH SCHOOL ............. 104

III. BIBLIOGRAPHY .............................. 105 
CHAPTER I

INTRODUCTION

\section{A. The Part-time Working Student and the High School}

For several years, prior to World War II, the hlgh school student who participated in a part-time job outside of school hours often did so against the advice of his elders and school officials. Such a practice was usually frowned upon as being harmful to the health and school work of the student. Possibly there was a basis for this contention since exploitation of youth by employers was not uncommon. Osually, the harmful offects overshadowed any possibility that, if properly supervised and co-ordinated by the sohool, a part-time job might bocome a vital part of the total education of youth.

The problem of the part-time working student remained, in the majority of high schools, one of only passive concern until the war years. During these years, critical need for workers in industry and business served as a magnet which drew thousands of youth, some on a part-time basis - some completely, from the high school. Prompted by attractive salaries and national patriotism, school-leaving youth became a problem of very serious concern in most high schools in the United States.

This accelerated problem was treated by many of the secondary schools as a troublesome one which they could not ignore but must tolerate until the end of the war would bring normal times and relief from an evil which they thoughtto be of temporary nature. Others, 
who were more progressive minded, recognized in this situation an inraluable educational device if it could be brought under the supervision of the school; they began to experiment with it as such.

\section{B. Statement of the Problem}

Is it possible for part-tine work to become, under the auspices of the school, with the cooperation of the community, an invaluable service to the high school youth of America in aiding them to find their proper place in the 11 fe of the community and at the same time provide the community with more matiure, exporienced, and satisfied oftizons upon their advent into adult life? Or, is this a problem which has so littlo value or merit that nothing more should be done about it other than to continue a polioy of toleration or abatement with the hope that it will eventually "run its course" and lose its significance?

It is the oonviotion of the writer of this thesis that the former hypothesis embraces moro logio and that it merits the clese sorutiny of those who are interested in the welfare and oducation of Amerioan youth.

Foeling that this hypothesis does have merit, the writer decided that a comparative study of part-time and non-working students in a typical American high school might reveal some very interesting facts about the supposed differenoes in these types of students, suoh as difforencos in (1) ago, (2) scholastio attainment, (3) plans for further oducation, (4) plans for future careers. (5) attitudes toward work, and (6) attitudes toward the noed for nore vocational guidance, This study might reveal, alse, suoh useful information about the working student as (1) the percentage of the total school onrollemnt constituted by this group. (2) evidence of employer exploitation, (3) effect of a 
part-time job upon school work, and (4) suggested areas of useful guidance and supervision. Finally, useful information might be ebtained on the non-working students, such as (1) why these students do not participate in part-time employment, and (2) their attitude toward such a praotice by other high school students.

If such information can be brought to light, the writer feels that 1t can be profitahly utilized by school administrators in any plans which they may have for vitalizing an organized work-experience program in their own school system. At least some of this information might lead to better understanding of the etudent body in general by the school administration in the direction of future school policies toward the fulfillemnt of student and community needs. The writer by no meens visualizes a complete solution to the problem of the working student as an ultimate result of this study. Enlightenment is the primary concern and the desired result.

\section{Interests Motivating This study}

The writer of this thesis has been for the past two years associated with the Alex G. Barret Junior High School of Louisville as a teacher of general soience, general mathematios, and physioal education. It is quite obvious, therefore, that the interests motivating this study did not grow out of his immediate employment. They are, however, personal interests that have accumulated over a period of years. There are at least four of these interests.

- First, the writer has a profound interest in the problems of youth and their welfare and in the field of vocational guidance. Second, the writer, of necessity, was a part-time woring student at a very early high school age. He is of the opinion that experiences 
gained on various types of part-time jobs while in high school and college were of tremendous value to him as a part of his total education. He believes, however, that these experiences might have been oven more meaningful and much more ploasant had they been obtained under the direction and supervision of the 8 chool.

Third, a recent experience with younger brother, who left school in the last year of his high school career to take a full-time job, created a now interest in the topio. The writer wonders if it would not have been possible, through an organized work-experience progrem, to have interested this youngster in the completion of high school and, at the same time, satisfied his dosire for omployment.

Finaliy, the decision to make this study came whon the writer was enrolled in Dr. Htlde Throlkeld's graduate course in Vocational Guidance at the University of Louisville in the spring of 1947. Dr. Threlkeld asked him to make a special report to the class on the topic of Work-Experionoes in High Schools. The proparation of this report created a desire to make a more intensive study on the topic.

The study reported in following chapters, therefore, is the result of the accumulation of personal interests in the subject over a period of years. Although personal interests motivated the study, the writer endeavored to conduct it in an open-minded manner, free of prejudice.

\section{Louisville Male High School}

After considerable reading and study on "Work-Experience", the writer approached Mr. A. E. Kalmer, doan of the Louisville Male High School, regarding the possibility of using that sohool as the subject of such a study. Mr. Kalmer shared the writer's interest in the plan and, in December 1947, made an appointment for him to discuss his 
plans with Mr. W. S. Milburn, principal of the sohool. Mr. Milburn expressed interest in the plan and gave his consent to prooeod with it in Louisville Male High School. Mr. Milburn, Mr. Kalmer, the faculty, and the entire sohool were most helpful and cooperative throughout the study, and the writer is deeply indebted to them for their kindness and their pationce.

\section{(1) Historionl Information}

Publio senior high sohools in Louisville are all, with the exception of Theodore Ahrens Trade School, non-ooeducational. Louisvillo Male High Sohool is one of the oity's two boys' schools. It was opened in 1856 at Ninth and Chestmut Streets under the name that it uses today. Rotaining this name, it was moved to the present location of Thoodore Ahrens Trade School on First Street near Chestnut in 1894.

After 21 years in this location, it was consolidated with the Wanuel Training High School under a new name, the Louisville Boys High School, and moved into the building wich it now occuples at Brook and Breckenridge Streets. This building was erected "at a cost of over a quarter of a million dollars".1

The consolidation of these two schools lasted until 1919 when they were gain separated and their original names restored. The Hanual Training School moved to new site and Louisville Kale High School remainel the Brook and Breckenriage looktion, its present site.

(2) School Fhllosophy

When founded in 1856, Louisville Male High School reflected the philosophy of former academic institution upon which it was based. 2

1. Loulsville Male High School, The "H" Book, 23rd odition, p. 9. 2. Ibid., p. 9 . 
The philosophy of the school has undergone continual change with the changing of the times, but even today it is often regarded as a "college preparatory" type of high school. The school itself takes pride in its outstanding achievements in this capacity throughout the years of its existence but desires to point out that "the history of the school from its beginning is the story of continuous efforts to adjust itself to the needs of the community". 1

In answer to the writer's query in regard to the present philosophy of the school, Mr. Kalmer presented him with a mimeographed copy of a statement of School Philosophy which represents the compilation of individual statements made by the school faculty and reads as follows:

The public school is an institution created by society to perpetuate itself by disseminating among its youth a comon language, common knowledge, common attitudes, common ideas and common ideals. The background of this common culture begun in the elementary school is broadened and intensified in the secondary school. The latter also seeks further to insure social stability by helping the young to understand the privileges, obligations, and general significance of citizenship in a democracy.

Within the framework of the social process of education it is highly desirable to allow the individual the highest degree of self-realization compatible with the general wolfare. This provision is necessary to insure to the individual his personel worth, dignity, self-esteem, initiative and economic sufficiency. The unity and stability of a democracy is peouliarly dependent upon good leadership. For that reason the school is charged with the responsibility of discovering potential leaders and giving them opportunities and encouragement for developing thoir spocial abilities.

The currioulum best suited to the purpose of education consists, in the main, of knowledge, culture, values, ideas, and ideals which the history of the long struggle toward civilization has proved to be lasting.

The teacher best qualified to educate the youth will have a broad cultural education and sterling charactor. He must be capable of making oritical examination and sound appraisal of the educational theories, fads and panaceas

1. Louisville Male High School, op.cit., p. 9 
which beset him. The teacher who is unstable is not fit to lead or direct youth to social stability. Bmphasis in the teaching process should be on content rather than on method and technique.

Through this statement of school philosophy one may gain an insight into the purposes and intentions of Louisville Mele High School in the training of youth.

(3) Enrollment

The enrollment of Louisville Male High School at the time this ourvey was made (January 1948 - near the close of the fall semester), according to the school records, was 1220 . This total onroliment consisted of 328 seniors, 417 juniors, ard 475 sophomores; it was representative of every oominuity in Loulsville and of several suburban areas. Thus, the influence of the school is projected into the whole of Louisville and its diversified areas.

\section{(4) Faculty}

With the exception of one librarian, the faculty of this school is entirely male. Faculty membership, including the principal, assistant principal, dean, and two librarians, totals 50 in number. In adition to this regular school feculty, the United States Army provides six extra members for the purpose of militery instruction and drill which became a part of the school curriculum in 1896.

A total of 96 college and university degrees are held by the regular faculty, representative of 22 universities, 2 law schools, and numerous colleges and teacher institutions. These 96 degrees are distributed in the following proportions 1

\section{Lousiville Male High School, op. cit., pp. 15-19.}




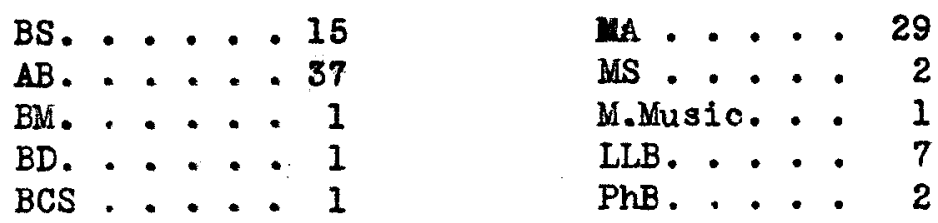

This information would, obviously, suggest a faculty which is well-trained and possessing a desirable variety of experiences, interests, and outlooks. As indicated above, at least five of the faculty hold two bachelor degrees and more than half hold one or more graduate degrees.

E. Method of Obtaining and Compiling Data

Just before the Christmas holidays atudent questionnaire wes tested on 50 students. This questionnaire was found sultable for the purpose intended and, with a few minor corrections, which did not change its character in any respect, was made available to the remainIng 1170 students near the close of the fell semester in Jamuary, 1948. The students were given time to fill out the questionnaire in a special homeroom period.

of the 1220 students enrolled at that time, 1055 filled out the questionnaire which represents an approximately 86.5 per cont sampling of the total school enrollment. Distribution of these 1055 students among the three school grades as compared to the total enrollment in these three grades was as follows:

\begin{tabular}{|c|c|c|c|}
\hline $\begin{array}{l}\text { School } \\
\text { Grades }\end{array}$ & $\begin{array}{l}\text { Total } \\
\text { Enrollment }\end{array}$ & $\begin{array}{l}\text { Number who Filled } \\
\text { Out Questionnaire }\end{array}$ & Sampling \\
\hline $\begin{array}{l}\text { Senior } \\
\text { Junior } \\
\text { Sophomore }\end{array}$ & $\begin{array}{l}328 \\
417 \\
476\end{array}$ & $\begin{array}{l}323 \\
356 \\
323\end{array}$ & $\begin{array}{l}98.5 \% \\
85.4 \% \\
68.0 \%\end{array}$ \\
\hline
\end{tabular}

As indicated above, the sampling of the seniors represented nearly the entire enrollment in that grade. Even the 68 per cent sampling of 
the sophomore enrollment would be considered a good one in most any sort of survey.

The results of this study were based almost entirely upon the date obtained from this student questionnaire. In the use of a questionnaire in making this study, the writer was well aware of the fact that the reliability of data obtained by this method is often questioned. The reason for the use of this method, however, was decided upon because of the extensive nature of the study to be made. In using the questionnaire method, the writer kept in mind the following statement made by $\mathrm{Dr}$. Hilda Threlkeld concerning the use of a questionnaire in a survey. ${ }^{1}$

Fundamentally, questionnaire deals with what poople think instead of what they do. The latter may be observed and, if not subjeot to misinterpretation or bias by the observer, may be recorded as accurate data. Again it may be argued that what people actually think may be regarded as a true expression of their real selves, as opposed to what they reveal but partially in overt action.

Several of the questionnaires were not fully completed, but the majority gave the impression of heving been taken very seriously. Only two were completely discarded because of evidence of lack of sincerity. The rest of them were regarded worthy of compilation as reliable information.

This questionnaire will not be reproduced in this pert of the paper, but the full text may be found in the Appendix.

Data obtained from student replies to this survey were compiled under the two general headings of "Working" and Won-Working Students". These two larger hoadings were broken down further and classified according to the grade levels of each group - Sophomore, Junior, and

1. Threlkeld, Hilda, The Educational and Vocational Plans of College seniors, p. 6 . 
Senior. This method insured a truly comparative study of the working and non-working students as well as an opportunity to study each group separately.

$$
\text { F. Organization of this Thesis }
$$

Including this "Introduction", the writing of this thesis has been organized under six chepter headings, namely (II) Background, (III) The Working Student at Male High and His Job, (IV) The NonWorking Student at Male High, (v) Comparison of Working and Non-Working Students, and (VI) Conclusions and Recommendations.

Chapter II provides a background for the presentation of this study based upon the experiences and opinions of others and the findings of other studies made on this same topic, rolated topics, and on the general topic known as Work-Experience.

Chapters III, IV, and V contain the findings of the writer's study A Comparative Study of Part-Time and Non-Working Students at Louisville Male High School. Chapter III, is according to the opinion of the writer, the most concentrated part of the study.

Chapter VI represents the writer's conclusions on the findings of this study and the recomendations he would make as a result of them. 


\section{CHAPTER II}

\section{BACKGROUND}

\section{A. Introduction}

Most any study, regardiess of its nature and soope, is usually conducted in the light of the opinions and the experiences of others; or of the findings reported on other studies made on the same topic, related topics, or on field which embodies many of the same principles and problems. Such has been the case in the making of 1 Comparative Study of Part-time and Non-Working Students at Louisville Male High School.

As a baokground for this particular study, the writer made considerable research in a larger field known to vocational guidance workers as Work-Experience. The primary purpose of this chapter, then, is to provide necessary background on this larger field for the presentation of findings in a component field, Part-time Work, in the forthcoming chapters.

\section{B. Work-Experience Defined}

Work-experience, as a term, is elmost definitive in itself. Like most terms that come into extensive use by many people, however, it invites varied opinions on its deoper meaning and its actual scope. All who use the term today, therefore, are inclined to define it according to their own convictions or as it applies to any partioular situation or area. 
A broed and quite generally accepted definition of the term includes any and al. of the experiences of the individual which contribute to the development of desirable work habits, such ast initiative, selfreliance, responsibility, cooperation, promptness, and industriousness. J. Paul Leonard summerized the aspects of this general viow in an address delivered before the Regional meeting of The National Association of Secondary-School Principals in Atlenta on February 17, 1942, when he stated that "work-experience for developing democratic living should start in the home before the child even enters school". " Such experiences of the child in the home as. picking up his own clothes and keeping his own room in order would be a start in the acquiring of valuable work experiences. Upon entering school he would add to these home chores the responsibility of caring for school property and the experiences of sharing school tasks with others. The child assumes more and larger responsibilities at home and at school as he pregresses through the elementary school and into the secondary school.

Work-experiences gained by youth in the high school period is that part of the "general term" with which this study is conoerned. A. further narrowing of the term is made, however, to include only those work-experiences of high school youth gained through actual participation in a part-time job.

Work-Experience, then, might be regarded as those experiences of high school youth obtained under actual working conditions which tend to introduce them to the adult world-of-work and which tend to help them "to develop salable skills and those understandings that make the

$$
\begin{aligned}
& \text { 1. Leonard, J. Paul, "Work-Experiences in Secondary Education", The } \\
& \text { National Association of Secondary-School Prinoipals - The } \\
& \text { Bulletin, }
\end{aligned}
$$


worker an intelligent and productive participant in economic life". 1 This is the definition of the term upon which this study is based.

\section{Some Areas of Need}

to Which Work-Experience Might Contribute

Recommendation of any practice for the extensive use of society in general should include possible contributions to certain needs of the individual and the community. Certainly it is not the opinion of the writer, nor does he think it the opinion of others who recommend workexperience, that provision of opportunities for such experiences can entirely fulfill these needs of the individual or the community, but it can contribute in a large measure to a more complete fulfillment. When certain individual needs of youth are satisfied, similar needs of the commity approach satisfaction. This is true because youth constitute a large pert of the community, and usually when a large part of a thing is improved, an improvement of the whole will result. The following observations, therefore, are made with this thought in mind, and most of the discussion is centered around the individual and his noods.

Some needs of youth to which work-experience might contribute are discussed in this section under the two headings; (1) Indoctrination in the democratic way of life, and (2) Bridging the gap between school and omployment.

(1) Indoctrination in the Demooratic Way of Life

J. Paul Leonard lists "development of understanding and experience in democratic living"2 as the first of three concepts which "give the

1. Gilchrist, R. S. and Gillies, Edith, "Imperative Need Number I", The National Association of Secondary-School Principals - The Bulletin,

2. Leonard, loc. cit., p. 30 . 
sotting for the nature and purpose of work experience". It can hardly bo donied that the individual definitely neods to find his place in the democratic community and, by working in oooperation with others in it, satisfy some of his own needs and desires while contributing to the well-being of all.

Dorothy Canfield Fisher recommends work-experience as a means of instilling in young people the feeling of "usefulness", a necessary part of indoctrination in the democratic way of life. In so doing, she quotes the timely words of Thomas Huxley that "the sense of uselessness is the severest shock whioh the human system can sustain". 1 To spare youth this shock and to help them become useful is a nocessity. Mason and Lesuer, in their study of Priladelphia school-work-programs, found that principals, school counselors, and employers alike felt that some of the benefits derived from such programs by youth were: "an added sonse of security, of 'belonging' to what was going on in the world"; "an increased ability to 'get along' with people"; and "a more vivid sense of the necessity of self-support". 2 Surely these aspects would contribute to the feeling of usefulness and, consequently, aid youth in becoming more useful citizens in any community.

In addition to this "feeling of usefulness", young people need to develop certain insights, understandings, and attitudes if indoctrination in the democratio way of life is to be complete. A special Committee on the Secondary-School Curriculum, reporting for the American Youth Commission in 1940, recommends work-experience on the grounds that "a pupil

\footnotetext{
1. Fisher, Dorothy Canfield, Our Young Folks, p. 261.

2. Mason, John E. and Lesuer, Bruce L., "A Work-Experience Program", The National Association of Secondary - School Principals The Bulletin, 28: 55, May 19 44 .
} 
gains, through the constructive handling of tools and materials, insight into the nature of things and insights with regard to his relations to his environment that he cannot gain in any other way". 1 Gilchrist and Gillies, in their statement of the Imperative Need NumberI of youth, point out that youth need to develop "those understendings and attitudes that make an intelligent and productive participant in economic life" and that "to this end, most youth need supervised work-experience as well as education in the skills and knowledge of their occupations".2 Would not the acquirement of these insights, attitudes, and understandings contribute to indoctrination in the democratic way of life? Logically, any person who is "an intelligent and productive participant in economio life" and who maintains a profound respect for the "nature of things" and his environnent will not become a hindrance to the life of his community. A period of tralning in which youth are prepared for useful citizenship will also contribute to the immediate good-life of the individual. Dr. Hamden L. Forkner, in an address to the American Association of School Administrators in Atlantic City on March 5, 1947, said that "most of the major orimes committed by young Americans are the result of their seeking to gain the ends which should be attained through honest workn". ${ }^{3}$ He also says that "The most common oriticism of young Americans when they go to work for others is that they lack a senee of responsibility and initiativen. If youth were provided with a program which would occupy much of their leisure time, satisfy their desires for spending

1. American Youth Commission, What the High Schools Ought to Teach, p. 20 . 2. Gilchrist and Gillies, loc. cit., p. 7 .

3. Forkner, Hamden L., "Work-Experience - A Must in Education", Teachers College Record, 48: 435, April 1947. 
money, and teach them the need of taking "rosponsibility" and initiative", would it not be a partial solution to the "juvenile delinquency" and youth crime in the United States? Dr. Forkner and others who are prominent in the field of education have that conviction and that this program should provide real, paid work-experiences on a useful job under supervision.

In all, there are many ways that supervised work-experience might contribute to the indoctrination of youth in the democratic way of life. As a final word on this topic, the writer quotes a statement of Dorothy Canfield Fisher on the importance of work in developing responsibility in youth, in which she says: 1

....practically all nomnal human beings neod from adolescence on, something which the course of book study cannot give them the irreplaceable vitamin of work and responsibility.

\section{(2) Bridging the Gap Betweon Sohool and Employment}

The transition of boys and girls from school life to work is frequently an abrupt process. Too often the world of education and the world of employment have held themselves too far apart to help the young person who is ready to onter employment make an easy transition from the status of student to that of worker. 2

According to Dr. Thomas L. Norton, there wero 4,700,00 young people in 1936 "between the ages of sixteen and twenty-five who were unomployed, out of school, and seeking work" ${ }^{3}$ This condition had changed considerably by 1942 when Reeves and Bell reported "at least $2,000,000$ youth were out of school and unemployed...."4 This picture,

1. Fisher, op. cit., p. 83 .

2. U.S. Office of Eduation, School and Work Programs, Bulletin No. 9, p. $\nabla$.

3. Norton, Thomas L., Education for Work, p. 139.

4. Reeves, Floyd W. and Bell, Howard M., American Youth Faces the Future, pp. 32-33. 
however, still was not too bright. It is pathetic that, in a period of war when industry was "on the boom" and there was a critical need for workers, 2,000,000 youth were still unemployed.

Certainly there are reasons for such rates of unemployment in the ranks of youth. What are some of these reasons? one of the most prominent reasons seems to be a lack of opportunity for youth to acquire adequate work skills and attitudes required by business and industry. Reeves and Bell found in a study of 4,740 occupations in forty industries that "employers stated that the successful performance of almost twothirds (67 por cent) demanded at least some work experience".1 This observation is of even more significance when compared to another study made by the American Youth Commission in cooperation with the United States Employment Sorvice of 4,000 youth registered as new applicants in the junior divisions of public employment offices. 2 This study showed that "among the 16-year-01ds, 99 percent, and among the 18-year-olds, 87 per cent, could not be given an occupational classification on the basis of work experience, training received, or a previous diagnosis. They were just applicants".

Such facts as the ones just stated serve to emphasize the dire noed of providing some kind of work experience for youth if they are to enter the adult world-of-work wi thout long periods of unemployment. Other studies show that young people are aware of this need, too. Ruth Eckert's stady of 1641 students who had left school from June 1936 to June 1937 in 51 communities and 62 schools in New York either by graduation or by withdrawal, showed that 3

1. Reoves and Bell, op. c1t., p. 31.

2. Ibid., p. 17.

3. Eckert, Ruth E., When Youth Leave School, p. 315. 
Many of the former pupils felt that they were not ready to begin work when they left school, that they had neithor the information nor the skills which would help them to begin work. Employers agreed with those statements and added that the attitudes of many of the pupils were such as to handicap them on their jobs.

She found that from 14 to 22 per cont of these youth who were unomployed gave as their roason for unemploymont the lack of adequate training. I In answer to the question "What are the problems which trouble you now that you are out of school?", most of the 1641 indicated problems of "vocational adjustment" such as getting a job, training for a job, advancing on a job, and planning a rocational future.2 These composed 39.8 per cent of all others indicated in other areas.

From the employed of this 1641 youth, Miss Eckert obtained similar views on the "lack of training". 3 She found that about half of those who had graduated indicated that thoy were untrained for their present job, and that more than 60 per cent of the withdrawals said lacked training necessary for work.

Further evidence that youth recognize their plight is found in a study made by Donald C. Doane in 1942 in the form of an inventory of 2,000 young people. They wore given a list of fifteen possible areas of need and asked to choose those which they desired most in the high school curriculum in the form of courses of study. 4 He found from the compilation of these choices that "How to find a job" was the most popular among 159 in 15 areas. Similarly, the five topics chosen by the largest number of the students had to do with "vocational adjustment"; and the nearer these students were to their last yoar of school, the more popular

1. Eokert, op. cit., pp. 250-252.

2. Ibid., p. 215 .

3. Ibid., p. 231.

4. Doane, Donald C., The Needs of Youth, p. 71. 
were these five topics. "Vocational guilance", says Doane, "thus is seen to be a major concern of youth...." It is quite possible that similar results might be obtained from such an inventory if placed in the hands of all American youth.

A common lament of youth, say Reeves and Bell, is "If I don't havo experience I can't get a job, and if I can't get a job I can't get experience". ${ }^{l}$ In view of the tendency of employers to require more and more work-experience as a requisite for employment, Reeves and Bell apprehend "some agency or plan capable of providing this experience" as the only means of solving this problem. Thomes Christensen of South High School, Worcester, Massachusetts, envisions "A part-time job - provided that sultable supervision is exercised - serves to give the pupil-worker a tryout in an actual job situation and occupational orientation that cannot be provided as effectively in any other way."2 W. F. Holtrop, shop instructor and coordinator of work-experience at Union High School of Corcoran, California, likewise feels that a work-oxperience program is one answer to this problem. He says, "Such experience leads to immediate employment of many whoreas for others it may have worthwhile exploratory value. $n 3$

The opinions of Christensen and Holtrop that work-oxperience is an important means of assisting youth to "bridge the gap between school and employment" represent similar opinions of many. Certainly that was the conviction of the writer which motivated interest in making this study.

1. Reeves and Bell, op. cit., p. 31 .

2. Christensen, Thomas F. "Work-Experionce in the Post-was High School", Schools and Society, 63: 52, January 19, 1946

3. Holtrop, W. F., "Work-Experience for the Small Secondary School", National Association of Socondary-School Principals - The Bullotin, 28: 59, Jamuary 1944 . 


\section{The Responsibility of Providing Work-Experience}

The need for work-experience is nothing new. Young people have always neoded to acquire skills and attitudes of work to propare thom for their place in the adult world. Means of securing this necessery exporience has not always been such a problem as it is today. This fact is well expressed in the following statement of Dorothy Canfield Fisher: 1

This need for genuine work experience in youth is spoken of es though it had burst on our country like a new discovery. The very words used in describing it are often new ones taken from the professional vocabulary of the "educational psychologist". But of course since the matter at issue is one of the aspects of humen life, it can hardly be now to life-experienced people. What is now is what is so often the only new eloment in the problems of modern industrialism - the fact that in modern conditions the problem doesn't solve itself as it did a hundred, or fifty, or even, to some degree thirty-five yoars ago.

In early America the provision of work-experience for youth was no problem. In those agrarian days "workvas a part of every young person's career, "n2 and provision was made by the families of the youth on the farms where most 1ived. For many, who did not receive these experiences on the farm, such training wes provided "by the handicraft shops in which they served apprenticeship."

Since work-experience was efficiently provided on the farms and in handicraft shops of early America, the youth of that day did not find themselves in competition with machinery or highly spooialized skills of industry. Dorothy Canfield Fishor sums this up, also, in single statement when she says, Mlost skills needed in pioneer conditions wero simple and manual ones, performed individually, or inside the loosest,

1. Fisher, op. cit., p. 22.

2. Christensen, 10c. eit., p. 52 . 
most temporary, most provisional organizations."l Few skills wore so highly specialized that training in them could not be provided on the farm. Even training for the professional skills was largely acquired by the apprenticeship mothod.

The situation of that day has, however, been gradually and consistently undergoing change. As stated by Thomes Christensen:2

Most parents now live in cities and ongage in thousands of different occupations far removed from the simple agrarian and craft rocations of their forefathers. Famliy training in effective work habits has become as extinct as the "dodo".

Unlike those early days when "parents were able, expecially in agricultural occupations end in many of the simpler crafts, to teach work habits without seriously interrupting their own activities", 3 parents no longer have the time, the means, nor the opportunity to provide such experiences for their children. The skills which were at that time simple have now become highly specialized. Those jobs of unskilled labor on which young people could learn working skills in the past have now been largely replaced by "labor-saving-devices" and machinery. Production in industry has been steadily increasing through the years and the number of men required has been decreasing. Dr. Norton says that "between 1920 and 1929 the output of manufacturing rose 40 percent, and the number of man-hours required dropped 2 per cent." 4 The gap between production and man-hours required, therofore, has broadened many times in the last two decades, and the plight of youth has become serious.

1. Fisher, op. cit., p. 39.

2. Christenson, Ioc. cit., p. 52.

3. American Youth Commission, op. cit., p. 15.

4. Norton, op. cit., p, 7 . 
Opportunities for work-experience have not come as naturally and easily for young people as they did in the past.

(1) The School and the Responsibility

For Providing Work-Experience

Since, as Fisher says "The ways of being useful have been so utterly transformed by industrialism that adolescents can no longer learn them in the old ways which were adequate fow generations ago", 1 it seems that some definite means must be provided whereby youth may be trained in useful work habits, Whore, then, if parents are no longer capable of making provision for this need, will young people find opportunities for it? Who will, and should be, responsible for it? Many, who favor work-experience, foel that it is a function for which the school should be responsible. Forkner says, "As young peoplo mature and begin to assume adult responsibilities, the school must assume an increasingly active part in co-ordinating out of school work." 2 He does not feel that the school is doing "its full job of education when large numbers of young people are not receiving preparation for living and working in a world where the great majority work." In a report propared for the American Youth Commission by a Special Committee on the Secondary Currioulum, the value of work-experience is classed as being "equal in importance with reading" and that it is "a means of oducation that has been neglected bocause it does not have the sanction of traditional school practice." 3 "Labor," says the Committee, "is the lot of man and it has not been recognized as it should have been in arranging institutional education."

1. Fisher, op. cit., p. 3 .

2. Forkner, loc. cit., p. 436.

3. American Youth Commission, op. cit., p. 15. 
A few of the many common statements relative to the responsibility of

the school toward making available work-experienoe to youth as a part of

the curriculum are:

(1) Howard M. Bell: 1

Teaching youth about jobs should be regarded as an essential part of preparing youth for living. Vocational information, particularly that which reflects conditions in local labor markets, should bo presented with the same sense of propriety that characterizes our teaching of algebra, history, and The Lady of the Lake.

(2) C. E. Rakestraw:2

In our cities.... sixty percent, and in smaller communities as much as eighty per cent, of the students of secondary age are not receiving the life adjustments training they need and to which they a entitled as American citizens. Real equality of opportunity in education awaits the solution of this problem.

(3) Thomas Christensen: 3

Changes in society, the needs of youth, and occupational trends all point to the conelusion that work experience should be considered as an integral element in the education of youth. Whether alone, or, as seems more reasonable, in conjunction with other institutions the school is to assume responsibilities for the transmission of the useful values associated with "work," it should be apparent that the problem will not solve itself.

\section{(4) J. Paul Leonard:4}

The high school owes no more obligation to preparing for college than for business or industris.l competency. The 1dea of the high school being a college preparatory institution is a feudal myth. Its first obligation is to the democratic state - the obligation to develop civic competency.

The majority, therefore, who feel that work-experience is important in the life of youth, feel, also, that it should be considered in the light of "general education" and that the seoondary school has a definite responsibility in making such experiences availablo. This is, also, the

1. Bell, Howard M., Watching Youth and Jobs, p. 252 .

2. Rakestraw, E. C., Training High School Youth for Employment, p. vii.

3. Christensen, loc. cit., p. 53 .

4. Leonard, 10c. cit., p. 30 . 
contention of the writer. He foels that the least the school should do is to put pupils "in contact with opportunities that give practical work training and prepare more directly than does ordinary school wo:k: for later employment by arranging with industries to give pupils parttime employment." 1

The United States Government, in the passing of legislative acts in Congress to promote vocaticnal education "in the fields of agriculture, trades and industry, home-making, commerce, and occupational information and guidance," omphasized the need of youth for work-experience and helped to place the responsibility for providing these experiences upon the school. Three such acts passed by the National Covernment since 1917, were: ${ }^{2}$

(1) The Smith-Hughes Act (Public Law \#347, 64th Congress) approved on February 23, 1917.

(2) The George-Deen Act (Public Law 637,74 th Congress) approved June 8, 1936.

(3) The George-Eorden Act (Public Law \#586, 79th Congress) opproved on August 1, 1946.

In passing these acts, the Naticnal Government did not attempt to organize or supervise any schools or classes, but made afailable financial assistance to those communities and schools desiring to organize such courses. These legislative acts indicate the interest of the Eederal Government for training youth for jobs and recognized the responsibility of the school for the provision of this training.

(2) A Combined Responsibility

The extent and success of eny training-for-work program introduced into the curriculum of any school would, however, depend upon several

1. American Youth Commission, op. cit., p. 18.

2. Rakestraw, op. cit., p.2. 
factors: the needs of the community, the needs of the youth in that community, the facilities veilable, and the cooperation of the variou institutions of the community. Only through the combined efforts and cooperation of the school and such institutions as the home, business, and industry could any plan for the education of youth function properly, whether in the training in work-habits or any other phase of the general education of youth.

In most secondary-schools, whether the school is aware of it or not, many students are engaged in part-time employment after school hours. It is obvious, too, that often these jobs are not of a desirable nature. Often employers have exploited youth on such part-time jobs in regard to age, wages paid, and hours of work.1 It should be quite evident, then, especially where such conditions are known to exist, that the school should assume the responsibility for "supervision of these experiences in order to make oertain that the young worker is not exploited and that his experiences are truly educational." 2 This is the contention of $\mathrm{Dr}$. Forkener, who goes further to surmise that a census of students in the school should be made and that trose who "are not having meaningful work-experience" should be required to do so before leaving high school.

According to those who recommend work-experience as a vital part of the education of youth, the responsibility for the planning and supervision should belong to the school, and industry should provide the laboratory for training and supervision on the job. It has been found that vocational shop courses offered by many schools are "by no means a solution of the problens of public schools." 3

1. Bell, op. cit., p. 61.

2. Forkner, loc. cit., p. 437.

3. American Youth Commission, op. cit., p. 10. 
Button and Amiss contend, as do many others who have had experience in this field, that "the best place to train for industry is within industry."l Schools are usually financially unable to provido necessary equipment and adequate training personnel for the proper functioning of such a program. A desirable solution to the problem, then, would not be for the school to assume all of the responsibility, but it should be a case of "shered responsibility;" an efficiently organized and coordinated program of "supervised co-operative training." 2

The following statement by J. Paul Leonard serves as a timely sumnary and conclusion to the contention that providing opportunities for work-experience should be "combined responsibility" of tie school, industry, and other interested institutions: ${ }^{3}$

The school should seek to correct these deficiencies of employment, but if the school is to capitalize on the growth gained by such activities it should team up with business, parents, and the government employment agencies and assist in planning, evaluating, and accrediting these programs of work experience in developing competence to do productive work.

.... Such experiences should be an integral part of the program of the school, but the actual experience should be attained at the cunter, desk, bench, or machine where such work will later be done. Business, labor, and industry will bo required to assume their respoctive responsibilities in plenning and operating such program. Preliminary education and guidance is a school function; work on the job under the supervision of the personnel of plents and business esteblishments is the responsibility of labor and business; evaluation and continued guidance is a shared responsibility.

\section{E. Recipients of Work-Experience}

Who shall be provided opportunities for work-experience? The answer to this question has been implied in preceding soctions of this chapter. Since it is a problem of major importance, however, a more

1. Sutton and Amiss, loc. cit., p. 411.

2. Ibid., p. 411 .

3. Loonard, 100. cit., pp. 34-35. 
direct treatment of it is made in this present section.

Organized work-experience programs have been, in the past, largely utilized as means of keeping in school those youngsters who had declared an intention of or who had indicated the probability of leaving school before graduation, and exclided those who were planning to enter tho professions and were enrolled in college preparatory courses. Recent progressive thought tends, however, to broaden this outlook somewhat.

Although it may be conceded that work-experience programs are valuable to the school-leaving group, "a declared intention to leave school before graduation should not become a prerequisite for admission to school-work program.1 "Neither should it be assumed that the retarded or beckweqrd pupil should be given work experience simply because he is not making progress in the school." A program organized solely upon tis basis will lose a great opportunity to serve to its capacity.

No argument can be given that an organized work-experience program will not offer highly valuable training for the youngster "who is going to work in industry or business and does not plan to continue his oducation in colloge." ${ }^{2}$ Primary concern should no more be entered solely upon this group than upon the first. Such pupils should be encouraged to participate, but a work-experience program should not be organized speoifically for their exclusive benefit.

There is no reason to believe that more effort should be expended in providing work-experience for either of these two groups than upon a third group who plan to enter professions and, consequently, to enter college. This group, too, has a need for suct experiences. The Special

1. Meson and Lesuer, loc. cit.. p. 53.

2. Leonard, loc. sit., p. 35 . 
Committe on Secondary Curriculum, in making its report to the American Youth Commission, gave at least one good reason for the inclusion of this group stating that "those who are to enter the professions need to labor at some period in their lives to gain an understanding and appreciation of what labor is." Would this not nerit the inclusion of this group in such progrem? Would it not provide them with training in the democratic way-of-life?

Dr. Forkner says, and this opinion is shared with others, that:2 Experiencing work is essential to the complete education of every young perscn. Whether the individual is to become a professional person, a housewife or simply an employee, his goneral education is not complete unless he has experienced the responsibility involved in a job.

An organized program for providing work-experience as a part of the secondary-school curriculum, then, "need not be restricted to any particular group or type of youth, 13 but should be planned to serve the needs of all youth for meaningful work-experiences as a part of their "total education."

F. Findings and Conclusions of Significant Studies Made on Organized Work-Experience Programs

As general rule, secondary-schools in the United States today are not accepting the responsibility for the provision of work-experience as a functional part of their educational programs. Many schools, however, during World War II found it necessary and desirable to incorporate organized programs in their curricula. Several studies have been made in recent years on such programs. A briof summary is made of two significant ones in this section of this chapter.

1. American Youth Comrission, op. cit., p. 20.

2. Forkner, loc. cit., p. 53.

3. Mason and Lesuer, loc. cit., p. 53. 
(1) A Study Made by the National Child Labor Commission

This study was begun in February 1945 for the National Child Labor Commission under the direction of Harold J. Dillon, Supervisor of Forks Adjustment in the Bureau of Youth Service of the Connecticut State Department of Education. It wes conducted in eleven communities in the United States, including Detroit, Grosso Ponte (fichigan), Los Angeles, Hinneapolis, Oakland, Orange (Toxas), Philadolphia, Sacramento, San Francisco, Torrington (Connecticut), and Tulsa. Only schools operating work-experience progrems on the "four-four" plan (four hours school four hours work) were included in the study.

The primary concern wich prompted the National Child Labor Committee to make this study was threefold: ${ }^{1}$

1. To make certain that industrial exploitation of youth does not occur under the guise of education.

2. To ascertain whether part-time employment of secondary-schbol youth.....can be brought under school supervision and control.

3. To sppraise the efficacy of the employment of school youth as supplementary to school programs in oncompassing the interests of ycuth.

\section{(A) Objectives of a Work-Experience Program}

On the basis of replies received from the schools included in this study, the following objectives of work-experionce program were most conmon to the majority of programs in operation: ${ }^{2}$

1. Keep in school students who might otherwise drop out for full-time employment.

2. Reduce hours and improve conditions of employment of students working outside of school hours.

1. Elicker, Paul E., Wartime Work-Experience Programs." The National Association of Secondary-School Principals - The Bul letin, 30: p. 16, oct. 1946 .

2. Ibid., p. 17 . 
3. Provide a method of plaoing students in work outside sohool hours more in line with their interests and abilitios.

4. Make easier the transition from school to work for students planning to drop out of school in the near future.

5. Improve school adjustment of students for whom the traditional curriculum was found to be inadequate.

6. Promote emotionel stability and social adjustment of many students.

(b) Evaluation of Wori-Experience Programs

Based upon the findings of this study, the following two statements were presented by the Committee as an evaluation of present operating programs and indications for future ones:1

1. Such programs, if they are to be continued, will need careful evaluation and the adoption of definite procedures and safeguards that could not always be provided in the many rapidly developed, and often large-scele programs that were set up under wartime pressures.

2. Such progrems, though they should not be regarded as the solutions of all the problems in secondary education, may become one of the many resources that will be developed to provide more meaningful educational experience for secondary school students than the usual school curriculum now does.

(o) Constructive Values of Part-time Work Programs

Three constructive values of part-time work programs were given by the Comittee in its report. These values are: 2

1. For many students a combination of school and work has definite educational and social values.

2. School-work programs may provide more appropriate jobs for students working outside school hours than students find independently.

3. The programs tend to interest some young people in remaining in school longer.

1. Elicker, loc.cit., p. 25.

2. Ibid., pp. 25-26. 
(d) Students for Whom Participation in a Part-Timel Work Program May be Valuabie

1. Those whom needs are not being met by the traditional school curriculum alone, many whom need concrete experience to give meaning to theoretical course work.

2. Those who need work as a factor in personal adjustment to acquire emotional and social stability.

3. Those who would drop out of sohool from a lack of interest unless given the opportunity by their secondary-school for a part-time school and part-time work program.

4. Those who will find in work experience an opportunity for developing vocetional selection.

5. Those who will make the transition from school to full-time employment more successfully through a work-experience program.

6. Those whose rocational interests might best be served through the opportunity to employ skills learned in school while still under the supervision and guidance of the $\mathrm{school}$.

(o) Selection of Student Participants

The Committee, feeling that "it is necessary that work experience be correlated with individual needs and interests", suggests the following procedures in the selection of students who are to participate in the work-experience program:2

1. Consideration of the reason for the individual's interest in work experience, or his need for it, as a factor in his educationel and social adjustment.

2. Thorough health examination.

3. Examination of cumulative record of the student.

4. Conferences with the student, his parents, teacher, and counselor.

5. An appraisal of total data to determine if the student's noeds and interests can bo met best through participation in a work experience.

1. Elicker, loc.cit., p. 25.

2. Ibid., pp. 28-29. 


\section{(f) The Curriculum}

Finally, The Comittee lists the following problems "Which need to be considered in organizing the school curriculum for students in school-work programs:"l

1. Discussion of problems encountered on the job and informetion pertinent to work experience should be given place in the ourriculum.

2. If possible, the currioulum should be so scheduled that work-experience students interested in extracurricular activities have some opportunity to participato.

3. Effort should be made to schedule required courses so that time will be avaliable for work-experience.

4. Guidance and counseling services should be expanded to make sure that the individual student benofits to the fullest extent possible from the work-experience program.

5. When work-study programs are organised in the schools, work experience should be given recognition in the curriculum as an integral part of the eduoation of the individual student.

(2) Joint-Study of the J. S. Office of Education and the Chil dren's Buroau of the U. S.

$$
\text { Departmont of Labor }
$$

This joint-study of the United States Office of Education and the Children's Buroau of the United States Department of Labor was begun in late 1944 and was concerned with "the welfare of the youth as to both his schooling and his work." It involved the war-time experiences of 136 schools of 55 citios in 37 states, and was contered only upon those programs in which students were released from school time in order to work on a part-time job for pay. It did not include co-operative programs nor programs operating under the National Vocational Education Acts.

1. Elicker, loc. cit., p. 31. 
(a) Purposes of School-and-Work Programs

The following purposes of school-and-work programs are sumary of the varied purposes indicated by the school officials and students in the 136 schools studied in this survoy ${ }^{1}$

From the standpoint of school officials:

1. To meet the wartime labor situation.

2. To furnish exploratory exporiences in the occupational world.

3. To keop students in school.

4. To help unadjusted students.

5. To help control conditions outside school hours.

From the standpoint of students:

1. To ronder patriotic service.

2. To earn money.

3. To substitute employment for study during part of the school day.

4. To pave the way for a full-time job later on.

(b) Types of Arrangements for Releasing

This study revealed a large variety of types of arrangements for releasing students from school to work in part-time jobs. Chief among these types were: ${ }^{2}$

1. Cooperative programs not reimbursed from Federal Funds.

2. Shortened school session for all.

3. Special school schedules for groups of working students.

4. Differing school schedule for oach working student.

5. Rolease for seasonal work.

1. U. S. Office of Education, op. cit., pp. 4-6.

2. Ibid., pp. 6-10. 
(c) Good Features of School-and Work-Programs

Based on information given by school officials in the 136 schools studied, the good features of work-experience program were: 1

1. Held many pupils in school who would under wartime conditions have dropped out of school altogether.

2. Provided source of incone for pupils in need of additional funds.

3. Provided an opportunity for some pupils to contribute to the war effort whilo continuing school.

4. Emphasized the neod for standards on hours and other working conditions of working students and for carefully developed and well-staffed school supervision over the arrangement.

5. Emphasized individual differences among pupils, both as to the combined school and work load which some pupils could carry and others could not carry, and as to kinds of work in which each could find educational value.

6. Stimulated the development of pupil personnel services and a recognition of their importance for oducational purposes.

7. Led to more flexibility in school programs, both as to content and schedulo.

8. Emphasizod school-community and school-industry relationships for co-operative purposes in oducational undertakings.

9. Stimulated schools to evaluate outside oxperience as to its suitability for the granting of school orodit.

(d) Bad Foatures of School-and-Work Programs

Based upon the same information, the bad features of a workexperionce program were found to be ${ }^{2}$

1. Many students participated whose interosts would have boen better served by full-time school; many were too young.

2. School-and-work schedules deprived many pupils of the chance to participato in important school activities both during and after school hours.

1. U. S. Office of Education, op. cit., p. 46 .

2. Ibid.. p. 46. 
3. Jobs were frequently routine in character and offered little in way of experience that could not have been gained by omployment for shorter hours outside of school time.

4. Coordinating services wer generally too limited for carrying a proper amourt of supervision over working conditions and experiences on the job.

5. Many pupils carried so heavy a school-and-work load as to endanger physical and mental health.

6. Thero was frequently too much night work and also too much interference with regular meals.

7. The relatively high earnings gave some pupils an exaggerated sense of money value of their service.

8. Money values rather than life-adjustment values were too largely the motivating force that lod students into school-and-work. programs.

9. Provisions were inadequate for capitalizing upon the work experience of the pupil for class instruction.

(6) Conclusions of the U. S. Office of Education on School-and-work Programs

In concluding its report on the study of School-and-Work Programs in 136 schools, the United States Office of Education listed and discussed several factors which should be given consideration in the organization of such programs in secondary schools in the future. To tho writer (1) selection of students who will profit from participation, (2) choice of suitable jobs, (3) operational controls of the program, and (4) permanent values of the program were pertinent and, therefore, he repeats them as part of the background to his study.

\section{(f) Selection of Students Who will Profit from Participation}

It was suggested that students be selected for participation in the school-and-work programs in accordance with the following individual differences: $:^{1}$

1. U. S. Office of Education, op. cit., pp. 48-49. 
1) Mental competence

2) Emotional stability

3) Social maturity

4) Personal interests

(8) Choice of suitable Jobs

Since much of the success of a work-experience program depends upon "the choice of work to which the student is assigned", the following criteria were suggested for this purpose, 1

1) Learning value of the job.

2) Working conditions on the job.

a) Environment should be wholesome.

b) Hours of work should not be too long.

c) Travel to and from the job should not be too long.

d) Adequate time needs to be allowed for lunch between sohool and the job.

e) Time to attend popular school events should be arranged.

f) Wages of part-time student workers should be comensurate with those of any others employed at comparable work.

3) Employer interest and supervision.

(h) Operational Controls of the Program

Certain operational controls were recomiended for the properly functioning program. These controls were as follows: 2

1) A pupil personnel service

2) Cooperation with parents

3) Assistance in obtaining work permits

4) Supervision on the job

(1) Permanent Values of the Program

Finally, the following permenent values were reconmended for the work-experience progran: 3

1) To the student worker it must provide an experience of such a nature that the working conditions will be safe beyond question and the educational values cannot be doubted.

2) To the employer it must supply help that, while inexperienced, is nevertheless useful and reliablo.

1. U.S. Office of Education, op.cit., pp. 50-52.

2. Ibid., pp. 52-54.

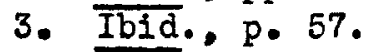


3) To the community it must be a means of advancing understanding and cooperation among school people, workers, and employers.

$$
\text { G. Summary of Chapter }
$$

An attempt has been made in this chapter to provide information and data on a large field, Work-Experience, as a desirable background for the presentation of the findings of a study made on a component field, Part-Time Work. The following is a summary of this background.

1) Work-Experience Defined: Those experiences of high school youth under actual working conditions which tend to help them develop cortain skills and understandings that will make them intelligent and productive participants in economic life.

2) Areas of Need to Which Work-Experience Might Contribute: The needs of youth for (a) indoctrination in the democratic way of life, and (b) bridging the gap between school and employment.

3) The Responsibility of Providing Work-Experience: Due to the change of American society from an agricultural to a highly specialized industrialized type, most of the responsibility has been shifted from the home to the school. An effective work-experience program would, however, depend upon the "sharing of responsibility" and the cooperetion of the school, industry, home, and the commity at large.

4) Recipients of Work-Experience: Work-experience should not be for the exclusive benefit of any particular group or groups of youth, but such opportunities should be extended to all youth. Work-experience is a vital part of the total education of all young people.

5) Significant Studies Made on Organized Worik-Experience Programs:

The final part of this chapter was devoted to the highlights of the findings and conclusions of studies made by the Child Labor Committee on 
Wartime Work-Experienoe Programs; and by the United States Office of Education in conjuntion with the Children's Bureau on School-and-Work Programs in $136 \mathrm{school}$ systems. 


\section{CHAPTER III}

\section{THE WORKING STUDENT AT MALE HIGH}

\section{AND HIS JOB}

Obviously, the prime concern of this entire study has been focused upon the working student at Male High School and the aspects surrounding his employment. Presentation of such facts and data obtained by this survey is the purpose of this imediate chapter. The conolusions drawn from the results of all the findings of this study, as reported in this chaptor, are treated in the final section headed "Surmary and Conclusions".

To make clear the nomenclature, "The Working-Student", it might be well to explain the distinguishing characteristics of this group. Only those students who, at the time this inquiry was made, were actively engaged in a part-time job either after school hours or on weekends for pay, are grouped in this olassification. Those students who indicated that they had held such jobs in the past but not at the present, those who usually worked during vacations or in the summer, and those who worked only spasmodically at odd fobs were classed as non-working for the purposes of this study.

A. Number and Per Cent of Working Students

The first concern of this study was to ascertain the proportionate number of working students inoluded in the total number questioned. Ey so doing, some idea of the percentage of the entire student body who were working might be very noarly approximated. Table I indicated the number and per cent of the total group who answered the questionnaire that were engaged in a part-time job. 
TABLE I

Number and Per cent of Working Students,

by Classes, as Compared with the

Total Number Who Filled

Out the Questionnaire

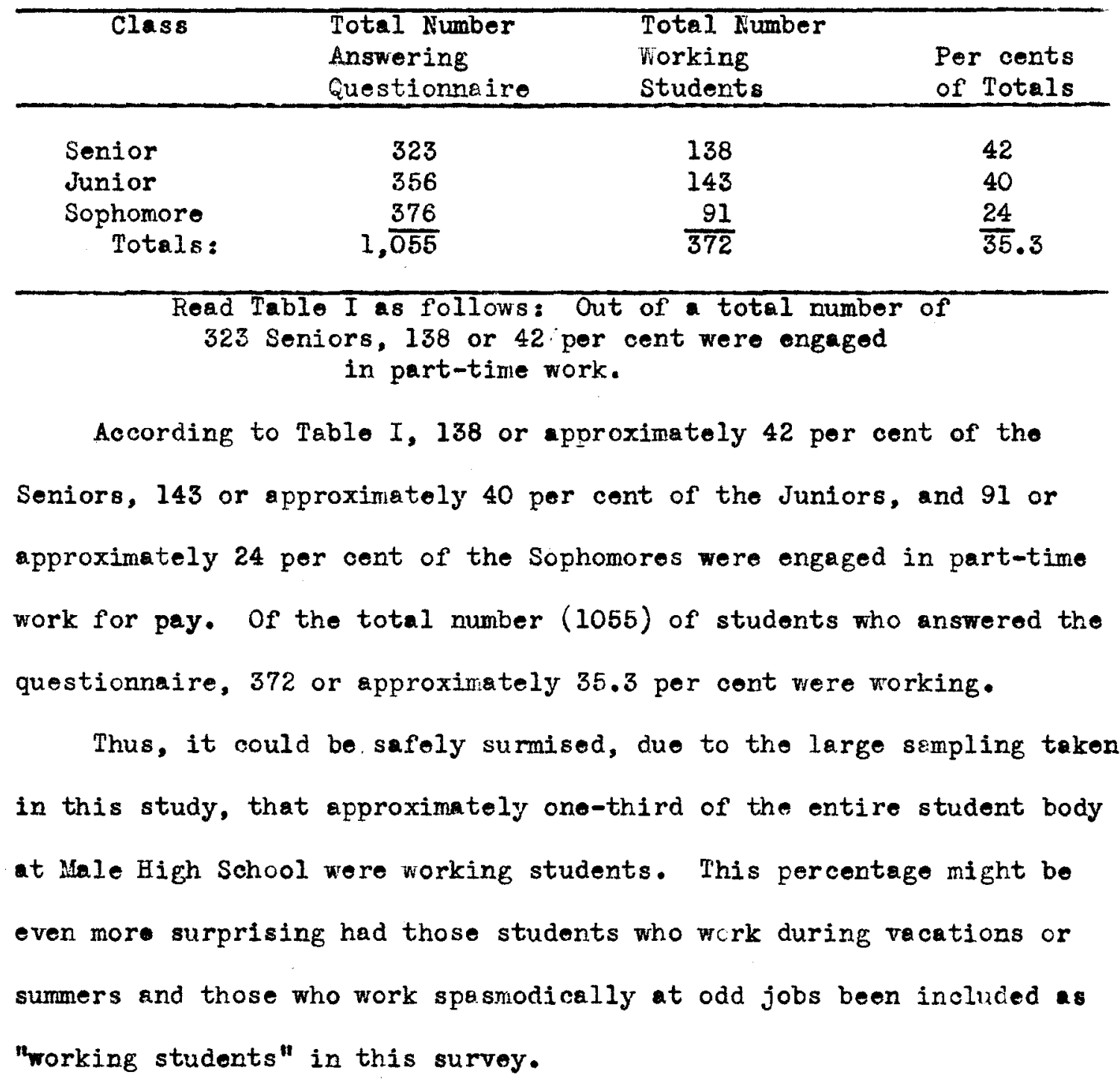

B. Why Students Work

Knowledge of the ressons for high school students engaging in parttime work should be one of the desirable results of study of this sort. Such information would possibly open up valuable avenues for individual or Group vocational guidance and sociel adjustment. 
The student questionnaire used in this survey included the question Why are you working?", directed at working students. To facilitate as nearly uniform answers as possible, three comprohensive statements of reasons for working which were to be rated by the student were supplied with the question. In addition to these three statements, a blank space was providod for "Other reasons" in case none of the throe supplied statements applied. The student was asked to leave blank those reasons which did not apply and to rate the others according to their importance by chocking oach with " "1", "2", "3", or "4" in a box at the left. Many students checked only one of the statements, some reted all three given statements and addod fourth, and in a fow cases two statements wero rated as of equal importance and checked with a "l". Tablo II includes these reasons for working and the number of times each was ranked first in importance.

\section{TABLE II}

Reasons Rated as First in Importance for Working and the Number of Times Checked in This Rating

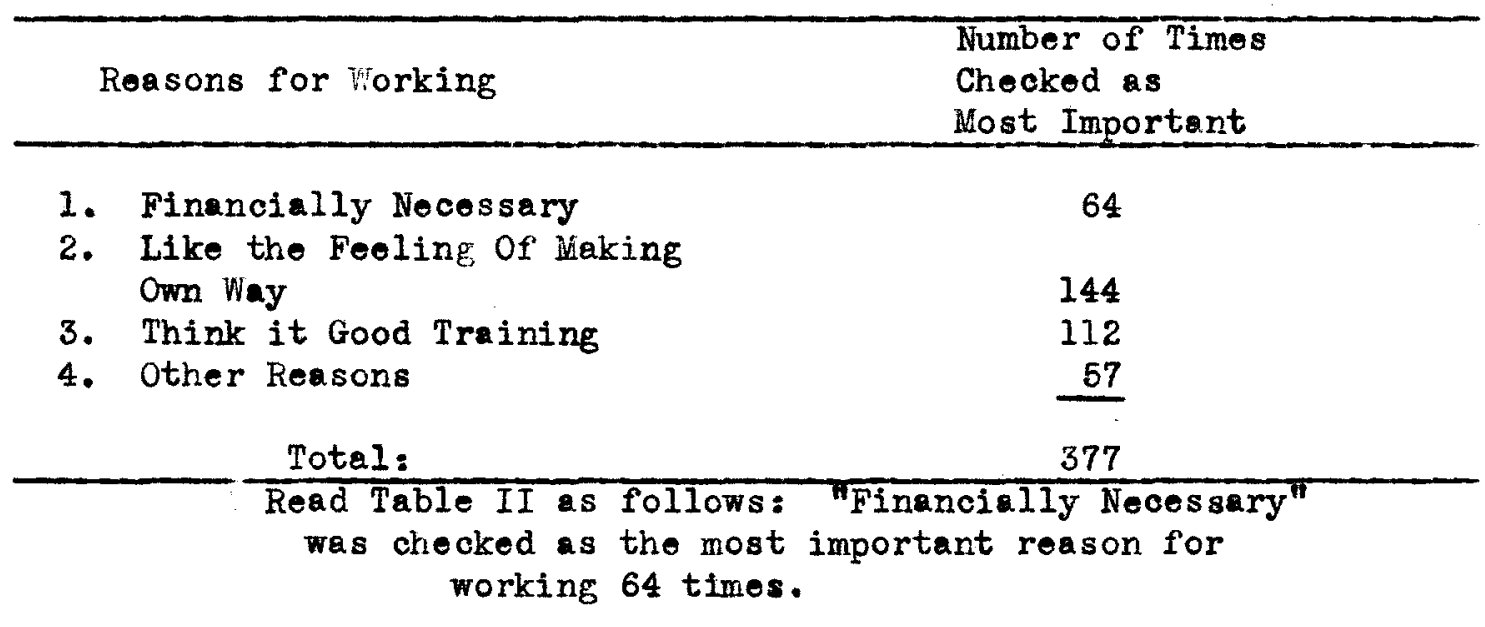

Table II indicates 377 as the total number of times the four statements were checked as the most importent reason for working while this 
study revealed only 372 working students. This was due to the fact that a fow of the students checked two statements as first and equal in importance.

The statement "Like the feoling of making own way" was checked in first place 144 times out of 377. "Think it good training" was next in popularity as it was ranked as most important reason for working 112 times out of 377. "Financially necessary" was checked 64 times and "Other Reasons" were given first place only 57 times. The results of these findings would indicate that the most important reason for students at Malo High participating in part-time work was either the desire for a feeling of independence or because the work-experience was considered good training.

Eleven "Other Reasons" were added to the three supplied statements. The frequency with which these other reasons appeared in 211 four ratings of importance wore as follows:

\begin{tabular}{lc}
\hline Othor Reasons for Working & Frequency Added \\
\hline For Spending Money & 44 \\
To Help Parents & 14 \\
Saving for College & 7 \\
Occupies Leisure Time & 5 \\
For Experience in Field of & 3 \\
Occupational Choice & 3 \\
Saving for the Future & 2 \\
Develops Appreoiation of Time & 2 \\
and Money & 2 \\
Like to Work & 1 \\
Good for the Physique & 1 \\
Experience in Moeting People & 84 \\
"I am Never Broke" & Total: \\
\hline
\end{tabular}

Close analysis of this list of "Other Reasons" for working would, doubtless, place practically all of them under one of the three given 
statements on the questionnaire. It is also interosting to note that out of the 11 other reasuns added by the students, 6 of them had to do with pay received from part-time work and were checked 71 times out the total 84 times for all of the 11 other reasons given. Thus, it would seem that earning money is closely associated with all reasons for the desire of: students to work.

\section{Ages of Working Students}

An important reason for making a study of part-time working students is to detect exploitation of youth who, according to State and National Child Labor Laws, are not of legal working age.

Table III indicates the number of working students in each year of age from 14 to 23 by school grades.

TABLE III

The Number of Working Students

in Each Year of Age 14-23

By School Grades

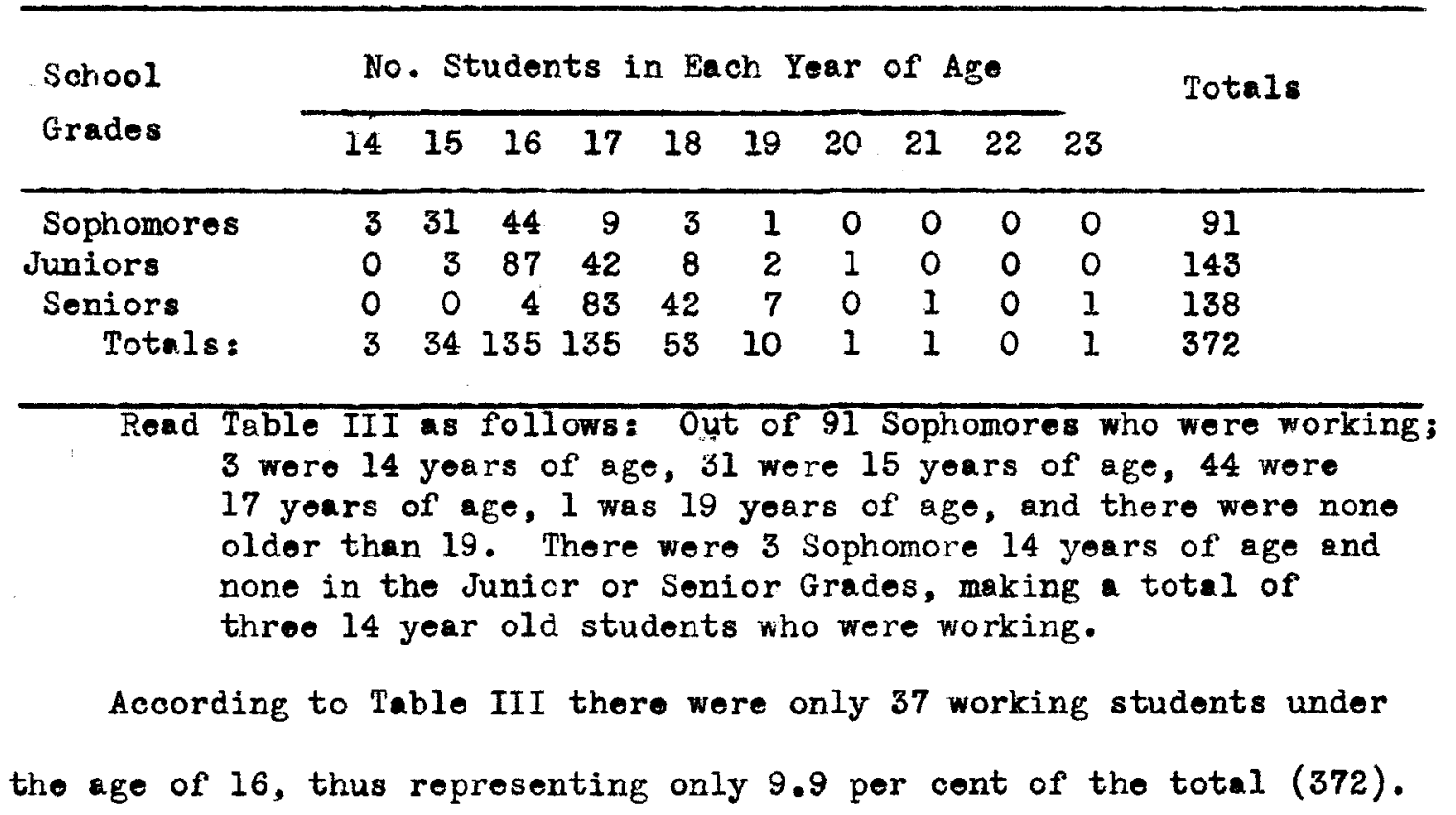


The largest number of working students were in the 16-17 year old group. This group totals 269 or 72.3 per cent of the total number of working students. Sixty-three, or approximately 17 per cent, were 18 to 19 years of ge. There were only 3 working students over 19 yoars of age (1-20 years, 1-21 years, 0-22 years, and 1-23 year of age). These 3 over 19 years old represent only about 0.8 per cent of the 372 working students.

The distribution of working students, by age groups, among the three school grade levels (Sophomore, Junior, and Senior) seems quite normal as most of the 14 and 15-year-olds were Sophomores, most of the 16 and 17-year-olds are both Junior and Senior, while most of the group over 17 years of ge wero Seniors. Such distribution of ages could bo expected in any average high school regardless of whether the students were working or not.

\section{Nature of Employment}

In a study of the working student in any high school, information obtained on the "Nature of Employment" might be valuable in two respects to reveal exploitation of student workers, and to provide information for rocational guidance. Thus, this study of the working student at Male High School attempted to find out the following things about student jobs: (1) typo of work, (2) hours on the job, and (3) salary paid. The findings on these three aspects are presented separately in this section of this chapter.

\section{(1) Types of Jobs}

To determine the type of work the working student at Male High School was doing, the question, "What sort of work are you doing?", was 
was asked on the questionnaire.

Answers to this question revealed that the largest per oent of the working students was omployed in some sort of merchantile toblishment. It was found that 154, or about 41 per cent, were thus omployed. Their duties included selling, stook-keeping, running errends, delivering merchandise, and the other usual types of jobs done by high school boys in such on establishment.

Table IV indicates the types of merchantile establishments omploying students and the number employed by each type.

\section{TABLE IV}

Typos of Morchentile Establishments and Number of Students Bmployed by Each

\begin{tabular}{|c|c|}
\hline $\begin{array}{c}\text { Types of Merchantile } \\
\text { Establishments }\end{array}$ & $\begin{array}{l}\text { Number of Students } \\
\text { Employed by Each }\end{array}$ \\
\hline $\begin{array}{l}\text { Groceries } \\
\text { Drug Stores } \\
\text { Clothing Stores } \\
\text { Department Stores } \\
\text { Shoe Stores } \\
\text { Poultry Houses } \\
\text { Florist Shops } \\
\text { Feod Stores } \\
\text { Wall-paper and Paint Stores } \\
\text { Sporting Good Stores } \\
\text { Surgical Supplies } \\
\text { Office Supplies } \\
\text { Sohool Supplies }\end{array}$ & $\begin{array}{r}79 \\
33 \\
16 \\
8 \\
7 \\
3 \\
2 \\
1 \\
1 \\
1 \\
1 \\
1 \\
1\end{array}$ \\
\hline Total: & 154 \\
\hline
\end{tabular}

The second largest group of the 372 working students were those employed as "paper-boys." There were 64 boys, or 17 per cent of the total-employed, in this group.

The third largest group were employed as "Ushers" by local theaters or by the municipal auditorium. This group was composed of 21 students, 
or about 5 per cent of the total group of working students.

These three groups totaled 239, and reprosented about 64 per cont of the 372 students engaged in part-time work. The remaining 133 working students ( 36 per cent) were found to be employed in 42 other typos of businesses, industries and jobs. Table V lists these other types of employment and the number engaged in each.

\section{TABLE V}

Other Types of Employment

and Number of Students

Employed in Each

Other Types of Employment

No. Students

Enployed in Each

$\begin{array}{lr}\text { General Office Work } & 12 \\ \text { General Selling } & 10 \\ \text { Laundry and Dry Cleaning } & 10 \\ \text { Service Station Attendants } & 9 \\ \text { Dance Band Musicians } & 9 \\ \text { Bowling Alley (Pin-setters) } & 9 \\ \text { Dairy Work } & 8 \\ \text { Banks (Messengers, errand boys, etc.) } & 6 \\ \text { Library - Public \& Church (Page-boys, etc.) } & 5 \\ \text { Printing Shops } & 5 \\ \text { Bakeries } & 5 \\ \text { Poultry Houses } & 3 \\ \text { Construction Work } & 3 \\ \text { Cafes and Restaurants } & 3 \\ \text { Concessions, Male High Gymnasium } & 3 \\ \text { Operating Own Eusiness } & 2 \\ \text { House Boys } & 2 \\ \text { Dental Laboratories (Apprentice Technicians) } & 2 \\ \text { National Guard and Other Military Reserve } \\ \text { Warehouse Work } & 2 \\ \text { Photography } & 2 \\ \text { Shoo Repair Shop } & 1 \\ \text { Parking Lot Attendant } & 1 \\ \text { Lumber Company (Errand Boy, Odd Jobs) } & 1 \\ \text { Church Janitor } & 1 \\ \text { Advertising Company } & 1 \\ \text { Ice Man } & 1 \\ \text { Tending Bar } & 1 \\ \text { Farm Work } & 1 \\ \text { Grounds Keeper (University of Louisville) } & 2\end{array}$




\begin{tabular}{lc}
\hline Other Types of Employment & $\begin{array}{c}\text { No. Students } \\
\text { Employed in Each }\end{array}$ \\
\hline Hospitil (Operating Room Technician) & 1 \\
Automobile Garage Work & 1 \\
Boat Club (Boat Miechanic) & 1 \\
Tractor Factory (Tractor Mechanic) & 1 \\
Church Musician (Organist and Choir) & 1 \\
Sewing Machine Ropair Shop & 1 \\
Stained Glass Window Manufacturing & 1 \\
Paint Manufacturing (Motallurgy, Pigments) & 1 \\
Plumbing (Apprentice) & 1 \\
Dancing Instructor. (Apprentice) & 1 \\
Plastering and Lathing (Ang & 1 \\
Junk Dealer (Weighing and Chocking) & 133 \\
\hline
\end{tabular}

As indicated by Table $\mathrm{V}$, the remaining 133 students, or about 36 per cent of the 372 working students, were found to be occupied in 42 different types of jobs, businesses, etc. Those 42 jobs rangod from such skilled jobs as automobile and tractor mechanics to the ordinary part-time jobs such as pin-setting in a bowling alley.

It is interesting to note that two of the students were engaged in their own businesses. One of these self-operated businesses was a small print shop and the other photography business operated on a small scale.

Certainly many of the part-time jobs roported by the working students indicate the possibility that at least some of the students are receiving some valuable and meaningful work-experience that would lead to a desirable career. Others, especially the one who reported that he was tending bar at bingo parties at the Labor Temple, would not seem to be receiving highly recommendable types of training. 
(2) Hours on the Job

The next interest of this study concerning "Nature of Employment" was to gather data on the approximate number of hours worked by individual students on their part-time job. Table VI indicates data obtained and compiled on the question "Approximately, how many hours per week do you work at this part-time job?"

\section{TAELE VI}

Number of Hours Worked Per Week and Number of Students Who Work Those Eours

\begin{tabular}{|c|c|c|c|c|c|c|c|c|c|c|}
\hline \multicolumn{10}{|c|}{ Hours Worked per Week } & \multirow[b]{2}{*}{$\begin{array}{l}\text { Total } \\
\text { Number } \\
\text { Students }\end{array}$} \\
\hline $\begin{array}{l}\text { School } \\
\text { Grado }\end{array}$ & $\begin{array}{l}1 \\
\text { to } \\
5\end{array}$ & $\begin{array}{l}6 \\
\text { to } \\
10\end{array}$ & $\begin{array}{l}11 \\
\text { to } \\
15\end{array}$ & $\begin{array}{l}16 \\
\text { to } \\
20\end{array}$ & $\begin{array}{l}21 \\
\text { to } \\
25\end{array}$ & $\begin{array}{l}26 \\
\text { to } \\
30\end{array}$ & $\begin{array}{l}31 \\
\text { to } \\
39\end{array}$ & 40 & 50 & \\
\hline Sophomoro & 7 & 26 & 18 & 18 & 9 & 2 & 3 & 0 & 0 & 83 \\
\hline Junior & 6 & 44 & 23 & 27 & 11 & 5 & 2 & 0 & 0 & 118 \\
\hline Senior & 9 & 23 & 22 & 26 & 22 & 13 & 1 & 3 & 1 & 120 \\
\hline Total & 22 & 93 & 63 & 71 & 42 & 20 & 6 & 3 & 1 & 321 \\
\hline
\end{tabular}

Read Table VI as follows: of 83 Sophomores who answered the question satisfactorily, 7 wero working from 1 to 5 hours per week, 18 from 11 to 15 hours, 18 from 16 to 20 , otc. There was a total of 7 Sophomores, 6 Junitors, and 9 Seniors or total of 22 who worked from 1 to 5 hours per week.

Table VI indicates a range of 1 to 50 hours worked per week by 321 students ( 83 Sophomores, 118 Juniors, and 120 Seniors) who answered this question satisfactorily. Of the 321 students; 291 , or about 90 per cent, were working less than the median number of hours (25) 3 178, or about 55 por cent, were working less than 16 hours per week; and only 10, or about 3 per cent, were working over 30 hours per week. Of the 10 students who were working over 30 hours a week, 50 per cent were Seniors. Only one student was in the upper extreme of 50 hours per week. 


\section{(3) Salary}

Remuneration for part time work proved to be very interesting factor of this study. For gathering information on the nature of student jobs, the working student was asked the question that is your approximate salary per week?" To deternine the hourly salaries the weokly salaries wore divided by the number of hours worked per woek by each student. Table VII indicates the salaries of the working students in 211 three school grades. The table shows certain salary rangos and the total number of students in each.

Tablo VII indicates a salary range of 25 cents per hour to $\$ 2.00$ per hour. One student made over $\$ 2.00$ per hour, but is not included in this range because of the unusualness of the case. He worked only one hour per weok as a churcin musician and chorister for which ho was paid $\$ 5.00$. The median salary for the remaining 320 students was $87 \frac{2}{2}$ conts per hour. Twenty-two per cent of the 320 students made a salary abovo this median. The node was 50 cents per hour with 85 students, or 26.5 per cent in this classification. Only 30 students, or about 9 per cont made less than the mode.

Musicians were the highest paid group of working students. Not including the one student who earned $\$ 5.00$ in one hour as church musician and chorister, nine students who played in dance bands (seo Table V) made an average of $\$ 1.79$ per hour.

The one student, indicated in Table VI, who worked 50 hours per woek, was paid a salary of $\$ 80.00$ or an average of $\$ 1.60$ per hour. This student was senior, veteran, married, and was paying for a home. He attended sohool only 10 hours per week to completo necessary requirements for a high school diploma. 
TABLE VII

Eourly Salaries of Students

and Numbor of Students in Each

Salary Range

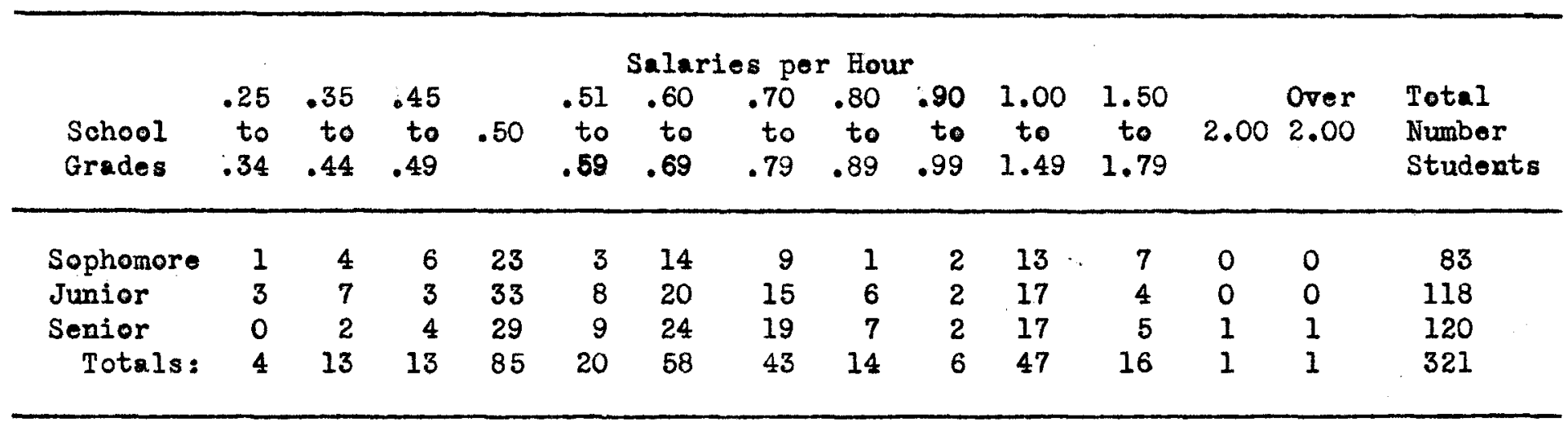

Read Table VII as follows: Out of 83 Sophomores, 1 student made an hourly salary of 25 to 34 cents, 4 made from 35 to 44 cents, 6 made from 45 to 49 cents, 23 made 50 cents per hour, oto. Of those students making from 25 to 34 conts por hour there was 1 Sophomore, 3 Juniors, 0 Soniors, and total of 4 in this salary range. Of the 321 students supplying information on salaries, 83 were Sophomores, 118 were Juniors, and 120 were Seniors. 
No outstanding difference in salaries made by the students in the three school grades was noted. The factor of age and of educational level seemed to have very little or no effect upon the salaries earned by the students.

\section{E. Attitudes Toward Work and Jobs}

In question number $7-k$ of the student questionnaire, the working student was asked "Do you like the work you are doing?" The student was asked to answor this question by encircling "yes", "no", or "not especially". Table VIII indicates the feelings of the working students toward the part-time job in which they wore ongaged.

\section{TABLE VIII}

Replies to the Question

"Do You Like the Work You Are Doing?"

\begin{tabular}{lcccc}
\hline $\begin{array}{l}\text { School } \\
\text { Grade }\end{array}$ & \multicolumn{2}{c}{ Answers to the Question } & & $\begin{array}{l}\text { Total } \\
\text { Number Students }\end{array}$ \\
\cline { 2 - 4 } & Yes & No & $\begin{array}{l}\text { Not } \\
\text { Especially }\end{array}$ & $\begin{array}{l}\text { Answoring } \\
\text { Question }\end{array}$ \\
\hline Sophomore & 68 & 1 & 21 & 90 \\
Junior & 104 & 8 & 28 & 140 \\
Senior & 95 & 4 & 39 & 138 \\
$\quad$ Total: & 267 & 13 & 88 & 368 \\
\hline
\end{tabular}

Read Table VIII as follows: Of the 90 Sophomores who answored the question satisfactorily, 68 liked their work, 1 did not like his work, and 21 did not expecially like the work they were doing. Sixty-eight Sophomores, 104 Juniors, and 95 Seniors liked treir work - a total of 267.

Table VIII indicates that out of a total of 368 working students 267, or 72.5 per cent, liked their work. Only 13, or 3.5 per cent, indicated that they difinitely did not like the work they were doing. Eighty-oight, or about 24 per cent, did not especially like their jobs. In each school grade, also, the larger per cent of the students indicated 
that they like their work. Only one of the 90 Sophomores stated that he did not like his job, while there wore 8 Juniors and 4 Seniors who definitely answered the question "no".

Regardless of the fact that about 72.5 per cent of all the working students liked the work they were doing, their answers to the question "Do you think you would like to make this type of work or business your careor?" indicated that most of them would not care to make it their life work. Table IX indicates the attitudes of 369 students toward making their present job their choice for a future careor. The question was answered by the encircling of "yes", "no", or "undecided".

\section{TABLE IX}

Replies to the Question

"Would You Like to Make this

Type of itork or Business Your Career?"

\begin{tabular}{llccc}
\hline $\begin{array}{l}\text { School } \\
\text { Grade }\end{array}$ & - Answers to the Question & $\begin{array}{l}\text { Total No. } \\
\text { Students } \\
\text { Answering } \\
\text { Question }\end{array}$ \\
\cline { 2 - 5 } & Yos & No & Undecided & \\
\hline Sophomores & 13 & 58 & 17 & 88 \\
Juniors. & 18 & 93 & 32 & 143 \\
Seniors & 26 & 86 & 26 & 138 \\
& 57 & 237 & 75 & 369 \\
\hline
\end{tabular}

Read Tablo IX 28 follows: of 88 Sophomores who answered the question satisfactorily, 13 felt they would like to make their job their career, 58 felt they would not, and 17 were undecided. Of those who answered "yes", 13 were Sophomores, 18 were Juniors, and 26 were Seniors.

Table IX indicates that of the 369 students who answered the question satisfactorily, 237 , or about 64.2 per cent definitely folt that they would not care to make thoir presont part-time job their career. By school grades 58 , or about 65.9 per cent of the Sophomores; 93 , or about 65 per cent of the Juniors; and 86 , or about 62.3 per cent of the 
Seniors indicated that they did not desire to make their job thoir

future careor. School grade, thus, did not seem to have any significant effect upon the way this question was answered.

F. Effects of Part-time Work Upon School Work

To ascertain the opinions of the working students regarding the effeot of a part-time job upon school work and upon their interest in securing an education, these two questions were asked; (1) "Do you think that your job has hindered your school work in any way?", and (2) "Do you think that your job has caused you to take more interest in your school work and in securing an education?" The results obtained by these questions, as indicated in Tables $X$ and $X I$, are gratifyingly in favor of students participating in a part-time job while in high school. Table $\mathrm{X}$ indicates the opinions of 369 working students on the first of these two questions.

TABLE X

Student Opinions on the Hindrance of Part-time Work to School Work

\begin{tabular}{|c|c|c|c|c|}
\hline \multirow{2}{*}{$\begin{array}{l}\text { School } \\
\text { Grade }\end{array}$} & \multicolumn{3}{|c|}{ Answers to the Question } & \multirow{2}{*}{$\begin{array}{l}\text { Total No. } \\
\text { Students } \\
\text { Answering } \\
\text { Question }\end{array}$} \\
\hline & Yes & No & Undecided & \\
\hline Sophomore & 3 & 75 & 10 & 88 \\
\hline Junior & 20 & 112 & 11 & 143 \\
\hline Senior & 23 & 102 & 13 & 138 \\
\hline Totals: & 46 & 289 & 34 & 369 \\
\hline
\end{tabular}

Read Table $X$ as follows: Of 88 Sophomores, 3 felt that their job had hindered thoir school work, 75 felt that it had not hindered, and 10 were undecided. Of the 46 students who felt that their work had hindered school work, 3 were Sophomores, 20 were Juniors, and 23 were Seniors. 
As indioated by Table $\mathrm{x}$, only 46 of the total 369 students who answered the question satisfactorily, or about 12.5 per cent, were of the opinion that their participation in a part-timo job had dofinitely proved to be some hindrance to their school work. Of the 369,289 , or about 78.3 por cent felt that thoir part-time job had not had any harmful effect upon their school work. Thirty-four, or about 9.2 por cent were undecided as to the effect of their job upon sohool work. School grades seem have only slightly affected the opinions of the working students on this question, although the per cent of students answering the question in the affirmative was slightly higher in the sophomore group than in the other two grades. Only about 3.5 per cent of the Sophomores as compared to about 14 por cont of the Juniors and about 16.6 per cent of the Seniors felt that their participation in parttime job had been a hindrance to school work.

Table XI indicates the answers of 370 working students to the second of these two questions.

\section{TABLE XI}

Student Opinions on Inoreased Interest in School Work Due to Participation in Part-Time Work

\begin{tabular}{|c|c|c|c|c|}
\hline \multirow{2}{*}{$\begin{array}{l}\text { School } \\
\text { Grades }\end{array}$} & \multicolumn{3}{|c|}{ Answers to the Question } & \multirow{2}{*}{$\begin{array}{l}\text { Total No. } \\
\text { Students } \\
\text { Answering } \\
\text { Question }\end{array}$} \\
\hline & Yes & No & Undecicod & \\
\hline $\begin{array}{l}\text { Sophomore } \\
\text { Junior } \\
\text { Senior } \\
\text { Totals : }\end{array}$ & $\begin{array}{r}46 \\
75 \\
75 \\
196\end{array}$ & $\begin{array}{r}23 \\
45 \\
44 \\
112\end{array}$ & $\begin{array}{l}21 \\
22 \\
19 \\
62\end{array}$ & $\begin{array}{r}90 \\
142 \\
138 \\
370\end{array}$ \\
\hline
\end{tabular}


Read Table XI as follows: of 90 Sophomores, 46 folt that their job had increased interest, 23 said that it had not, and 21 were undecided. Of the 196 students who felt that interest had been incroased; 46 were Sophomores, 75 were Juniors, and 75 wore Seniors.

Table XI indicates that 196 students out of 370 , or about 53 percent felt that their job had increased their interest in school and insecuring an education. Of the total, 112 , or about 30 per cent, felt that their job had not had any offect upon their interest, and 62, or bout 16 per cent, wero undecided as to the effoct.

School grade seemingly had very little effect upon the answers given to this question. There was a slight increase, however, in affirmative answers to the question with advancement in school grades46, or 51 per cent were Sophomores; 75 , or 52.8 per cent were Juniors; and 75 , or 53.6 per cent were Seniors. The increase in negative answers with advancement in school grade was, however, little more pronounced with 23 , or 25.5 per-cent of the Sophomores; 45 , or 31.6 percent of the Juniors; and 44 , or 31.8 per cont of the Seniors answering the question "no".

\section{G. The School and the Working Student}

A great number of educators are thoroughly convineed of the value of work-experience to boys and girls of the high school age. Despite the many and diverse mothods of providing such experiences, most educators agree that if real value is to be realized from its supervision, both in placoment and on the job, is a necessary factor. Some oven feel that unless these experiences are properly supervised they may be "Not only a waste of time but even a complete failure." 1

Louisville Male High School, although realizing the value of worktraining, has never adopted an organized and supervised program for 
the provision of this experience for its students. The extent of supervision for those students who do work has been the issuing of work permits (Soe Appendix for Permit used) for boys under 16 years of age as required by Kentucky Labor Laws ${ }^{1}$, and the oxcusing of some students from part of the school day to work. The school usually investigates to make certain that the pupil to whom a work permit was issued, or who is being excused, is actually working and the place indicated on the permit. Otherwise, it seems that in most cases the school is probably not aware of students who are working rior of the conditions under which they work.

of 370 working students who answered the question, "Doos the school know that you are working?"; 80 stated that the school know of their omployment, 81 stated that the school knew nothing of thoir employment, and 209 did not know whether the school was aware of their employment or not. In other words, only about 22 percent said that the sohool know of their employment, and about 56 per cent did not know whether or not the school was aware of their employment. Since the school makes no definite effort to find out abut students who are engage in part-time work, it is quite possible that there was no knowledge of the employment of the majority of the 209 who were not sure of the school's knowledge of their employment. Thus, it would soom that the school, besjdes providing no real suporvision, does not know about the employment of the majority of the working students.

Although Male High School does not att pt to supervise the working student on his job, it attempts to be of service where necessity is evident by excusing some students from part of the school day to work. Except 
for Seniors who are roquired to attend school only during hours neoossary for completion of high school credits for graduation, no student is excused more than one period in any one sohool day. Usually when a student is excused, it is the last period of the day. Answers to the question, "Are you being excused from part of your school day to work at this part-time job?", revealed the fact that comparatively few of the students who have part-time jobs are being excused to work. Out of 370 working students who gave satisfactory answers to this question, only 52 stated that they were being excused. Of this 52, or approximately 14 per cent of the 370,32 wero Seniors, 10 were Juniors, and 10 were Sophomores.

The number of hours worked by the group ranged from 4 to 50 per wook, or median of 22.4 hours. Thirty-nine, or 75 per cent of the 52 wore working the median number of hours or less per week. Only 12 were working as many as 25 hours or more per week of which 9 were Seniors.

Salaries for these 52 students ranged from 40 cents to $\$ 1.65$ por hour, or a median salary of 62.5 cents per hour. Thirty-one, or 59.6 por cont, were earning salaries above this median. Only 5 earned less than 50 cents per hour, and 8 exactly 50 cents. Only 2 students were earning the lowest rate of 40 cents per hour.

\section{H. Summary and Conclusions}

This chapter has been entirely concerned with the working student and his job. Of the 1055 students at Male High School who completed the questionnaire, 372 , or 35.3 por cont were engaged in part-time work for pay either after school hours or on woekends. Data on these working 
students have been compiled under the headings of (1) Number and Per Cent of Working Students, (2) Why Students Work, (3) Ages of Working Students, (4) Nature of Employment, (5) Attitudes Toward Work and Jobs, (6) Effoct of Part-Time Work Upon School Work, and (7) The School and the Working Student.

(1) Why Students Work

The most important singlo reason given by students at Malo High Sohool for working was the desire for a feeling of self-sufficiency. Second to this roason was that part-time work was "good training". The first of these reasons was given 144 times out of 377 as compared to 112 out of 377 for the second. Only 64 out of the 377 indicated "financial necessity" as their reason for working. To "earn spending money" was given 44 times as "Othor Reasons" for working. Thus, the financial phase of a part-time job was found to be very important. This phase of part-time work is a very important factor, but the United States Office of Education in its report on Wartime Work-Experience Programs conoludes that important as this factor might be, it should not be the primary purpose of an organized work-experionce progran.l The large number of students who indicated that they were working because it is "good training" is a favorable indication for such a program.

(2) Ages of the Working Students

As indicated by this study, 37 of the 372 working students were under the age of 16 , and 34 of this number had passed their 15th birthday. This, when checked against Kentucky Labor Laws, indicates very little or no illogal omployment. These laws state that:

1. U.S. Office of Education, op.cit., p. 56.

2. Dopt. of Ind. Relations, op.cit., p. 29. 
A work permit may, when the issuing officer is convineed that the need is sufficient, bo issued to a child who is under the age of sixteen yours but who has passed his fourteenth birthday, who holds certificate of complotion of an eight year elementary school course or an equivalent course.

Since this study was made, however, Kentucky has revised its Child Labor Laws in a bill passed in March 1948. The difference in the preceding law and the now one relative to age is that the new one restricts the type of work to be done by children under 16 and makes possible three types of permits. ${ }^{1}$ These are; a "General employment Certificate" which allows employment of youth between the ages of 16 and 18 who have completod high school, a "Vacation Certificate" which permits omployment of childron between the ages of 14 and 16 during vacations or outside of school hours, and "Special Certiticate" which permits the employment of children between the gges of 14 and 16 during the entire year "who have been found to be incapable of profiting from further schooling." Exploitation or illegal employment of high school youth at Hale Eigh School relative to age according to the state laws which were in effect at the time this study was made or according to the new Child Labor Laws was found to be practically non-existant. Male High is to be comnended on this phase of student employment and the issuance of work-permits.

(3) Nature of Employment

As al ready mentioned, "nature of employment" was considored to include the type of employment, hours on the job, and the salary paid. As for the factor "types of jobs", it was found that 154, or about 41 per cont, were working in some sort of merchantile establishment or rotail trade. Of the 136 schools studied by the United States Office of Education, this condition was invariably true. ${ }^{2}$ This study of the working

\footnotetext{
1. Commonwerlth of Kentucky, House bill No. 402, March 8, 1948, Secticns 3 and $9, \mathrm{pp} .1-3$ end $5-6$.

2. U. S. Office of Eiducation, op. cit., p. 13 .
} 
students at halo High School indicatod also, that studonts wore ongaged in some 40-odd other types of work other types of work other than in merchantile establishments and retail trades. Those included public service jobs such as restaurant work and gas station attendants, as woll as some jobs with a promise of future rocational possibilities, such as appronticeships in various skilled trades. This variety of work acoording to the study made by the Child Labor Comittee, is highly desirable and should be one of the primary aims of an organized work-experience program.

Examination of the typos of work reported in Table IV and V shows that very fow students were employed in jobs that were hazardous in nature. Those few that might be considered of such nature were filled by the older students and in accordance with Kentucky Labor Laws.1 Exploitation of this natue, therefore, is not evident to any great oxtent, if at all.

The medien number of hours worked was found to be 25 per weok with about 90 per cont working less than this median. The Kentucky State Labor Laws which were in effect at the time this study was made required that no child under 16 should work more than 6 days in one weok, more than 48 hours in one week, nor more than 8 hours in any one day. 1 Since only one student was working more than 48 hours per week and he was over 16, no illicit employment undor the old law was ovident. The now law places greater restriction on employment of youth in high school by requiring that no person under 16 shall, while attending school, work

1. Dept. of Ind. Kelations, op.cit., p. 32. Commonwealth of Kentucky, op.cit., section 3 , pp. 1-2.

2. Dept. of Ind. Relations, op.cit., p. 31. 
more than 3 hours on a school day nor more than 23 hours in a school week, and that no person 16 or 17 years of 2 ge shall work more than 4 hours during a school doy nor more than 28 hours a weok. 1 Exploitation, oven under this law, was not serious since 90 per cent were working less than 25 hours per woek. This now law, however, could present a problem that only a supervised work-experience program could satisfactorily cope with.

The modion salary of the working students was 87.5 conts per hour with 22 per-cent oarning more than the median. The mode was 50 conts por hour with 26.5 per cent in this classification. Only 9 por cont mado less than this mode. Similar to the report made by the Child Labor Cornmittee, these students at Male High wore being paid the "going wage". 2 It will be noted, also, (Table VII) that the majority woro earning above the minimum wage set by the Fair Labor Standards Act passed by Congress in June 1938 and revised in 1941.3 This minimum wage was 40 cents per hour.

The fact indicated relative to "naturo of employment" seems to show very littlo or no sign of serious exploitation of youth according to State or Fedoral Labor Laws. Guidance and counseling, however, is a much needed service which should be rendered to the working student.

\section{(2) Attitudes Toward Work and Jobs}

One of the most interesting facts revealed by this study of working students was thet, although 72.5 per cont of them indicated that they liked their work, 64 of them indicated that they did not foel that

1. Cormonwealth of Kentucky, op.eit., section 6, p. 11 .

2. Elicker, op.cit., p. 23 .

3. U.S. Dept. of Labor, Div, of Labor Standards, Federal Labor Laws and Agencies. Bulletin 1946, No. 79, p. 24 . 
this was their ocoupational cholce for the future. In view of the opinion that one of the desired results of a work-experience program is to help youth to make wise choice of their vocations, this would seem to be an adverse situation. Other values of work-experience could, however, oasily overshadow this condition. Even though these particular part-time jobs might not be the occupational choices of the students participeting in them, they might be of value in that the student may have gained in selfreliance from having found his own job, in self-discipline by working to hold the job, and he may "have developed a sense of how the community works by aiding in producing or diatributing goods." 1 If a work-experionce program is properly organized and supervised, these values alone would warrant the establishment of such a program and certainly would be beneficial to all students participating regardless of their plans for vocational future.

(5) Effects of Part-time Work upon School Work

The fact that 78.3 per cent of the working students at Male High School felt that their participation in part-time work had definitely had no ill-effect upon their school work and that about 53 per cent felt that this work had actually served to increase their interest in school work indicate the possibility that a properly organized and supervised workexporience program might serve as a means of making school seem more of a practicality and mocessity to high school studonts. Thus, work-experionce might inorease the desire of youth to stay in school longer and to seok higher levels of education and at the same time contribute to their total individual dovelopment into useful and satisfied citizens.

1. Leonard, loc, cit., p. 54. 
(6) The School and the Working Student

The extent of the superviaion provided by Male High School for Its working students was found to be limited to the issuing of work-permits as required by Kentucky Labor Lows and the excusing of a fow students from the last hour of the school day to work. Only 80 of the 370 working students indicated that the school definitoly knew of thoir employment, 81 were fairly cortain that the school know nothing of thoir employment, and 209 did not know whother the school was aware of their employment or not. Out of the 370 working students, only 52 stated that they were being excused from part of the school day to work, and part of these wero Seniors who were attending school only the required number of hours to complete required credits for graduation.

Study of the 52 students excused by the school to work showed that their median salary was about 62.5 cents per hour as compared to a median of 87.5 cents per hour for the total 370 . The median number of hours worked by these 52 students was 22.4 per woek as compared to a modian of 25 hours per week for the entire group. Although the median salary was less than that of the entire group of working students, only 5 of these 52 were earning less than the 50 cents per hour salary mode of the 370, and no student in the 52 was making less than the 40 cents per hour minimum salary set by the Fair Labor Standards Act. Since all the students who earned less than this minimum were those whom the school had not excused to work and since the hours of work of the 52 seemed to be slightly better than that for the 307 , the value of school supervision is indicated in small way. Thus, school supervision could possibly play vital part in improving the working conditions of students while, at the same time, helping to make work-experience real educational experience. 
THE NON-WORKING STUDENT AT MALE HIGH

All those students who were not actively engaged in part-time employment for pay wore classed as "non-working" for all purposes of this study. This chapter is a compilation of the data given by the non-working students concerning their attitudes on part-time work and their reasons for not working.

A. Number and Per cent of Non-Working Students

Table XII indicates the number of students who were classed as "non-working" out of the 1055 students at Male High School who filled out the questionnaire.

TABLE XII

Number and Per cent of Non-Working Students As Compared with the 1055 Who

Filled Out the Questionnaire

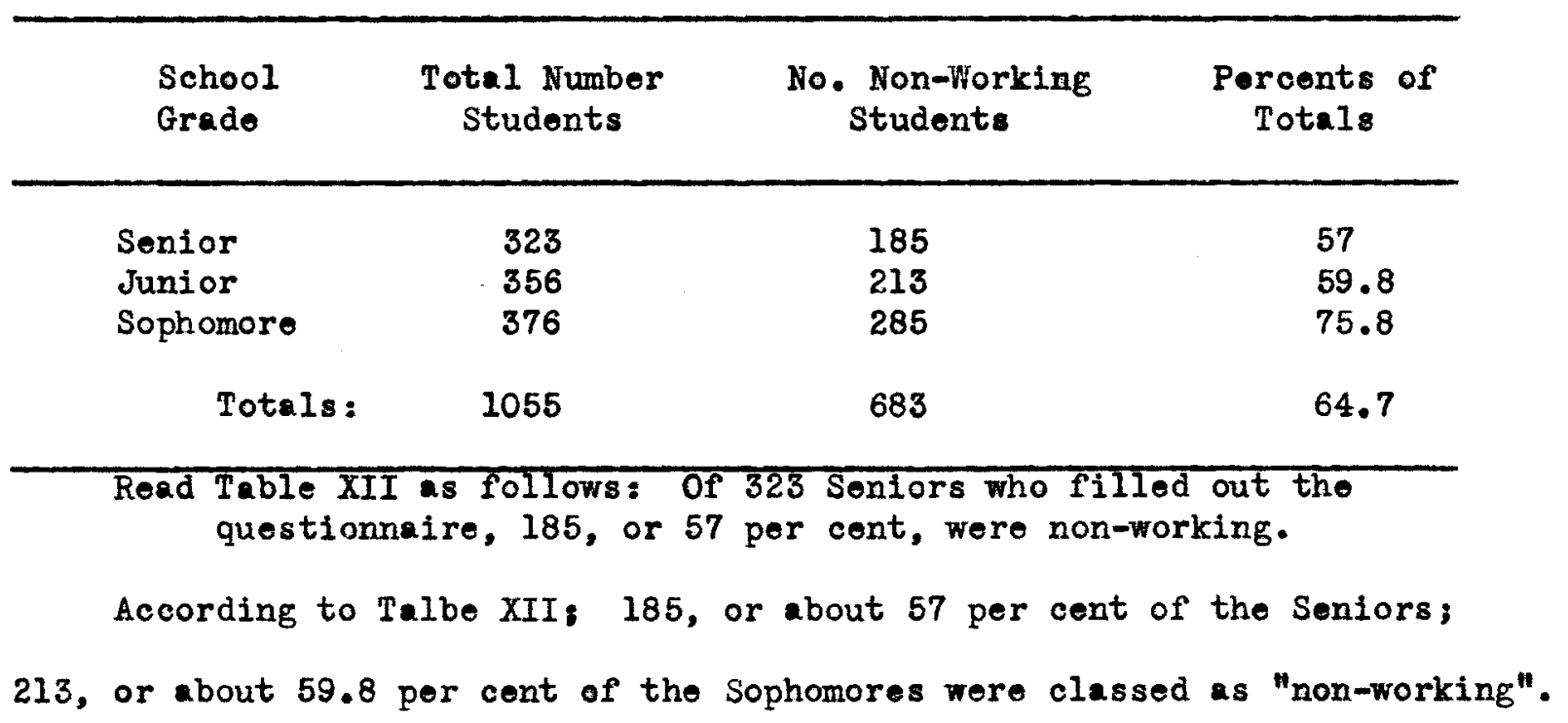


Out of the total of 1055 students who filled out the questionnaire, 683, or about 64.7 per cent, were not engaged in a part-time job for pay at the time this survey was made.

Table XII further indicates that of the three school grades, a greater per cent of the Sophomores wero not working than of the other two grades. This, without doubt, was due to the fact that a larger per cent of pupils in this grade were under age according to the Kentucky Child Labor Laws than those of the other two grades.

\section{B. Ages of Non-Working Students}

For the purpose of comparing the ages of working students with those of the non-working, information similar to that presented on the working students in Table III is given on the non-working students in Table XIII.

TABLE XIII

Number of Non-Working Students By Ages (14-22) and School Grade

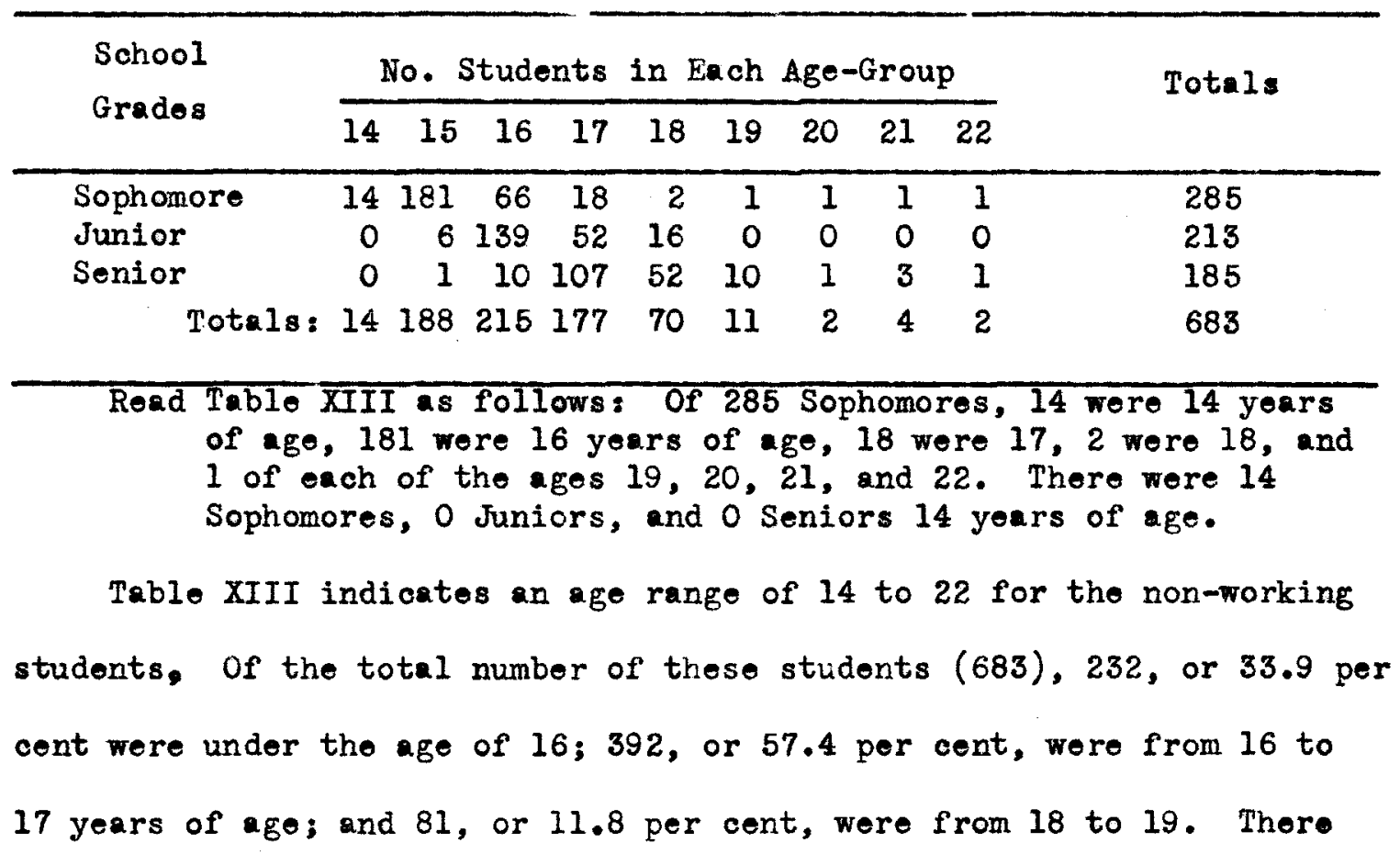


were only 8 students over the age of 19 , or about 1.2 per cent of the total. Of the 8 students over 19 years of age 3 were Sophomores, 0 were Juniors, and 5 were Seniors. There were only 2 students in the upper extreme of the age range, or 22 years of age.

\section{Why Students Do Not Participate in Part-time Work}

Feeling that a knowledge of the reesons why some students do not participate in part-time jobs might be of value in gaining a more complete insight into the problem of work-experience, the writer asked the non-working students the question "Why do you not have a part-time job." Five statements were supplied with the question which the students were asked to rate in importance as their reason for not working. A blank space was provided for the students to list "Other Reasons" in case none of the 5 given ones applied. Table XIV is a compilation of the statements checked as the most important reason for not working. It gives the five statements and the number of times each of these statements was chocked by the non-working students as their first and most important reason for not participating in a part-time job.

TABLE XIV

Reasons for Not Working and the Number of Times Rated as Most Important

\begin{tabular}{|c|c|}
\hline Reasons & $\begin{array}{l}\text { No. Times Rated as } \\
\text { Most Important }\end{array}$ \\
\hline $\begin{array}{l}\text { 1. Cannot secure a suitable job } \\
\text { 2. Need the time for school work } \\
\text { 3. Financially not necessary } \\
\text { 4. Parents will not permit } \\
\text { 5. Health will not permit } \\
\text { 6. "Other Reasons" } \\
\text { Total: }\end{array}$ & $\begin{array}{r}198 \\
178 \\
117 \\
35 \\
4 \\
102 \\
634\end{array}$ \\
\hline
\end{tabular}


Read Table XIV as follows: "Cannot secure a suitable job" was rated as the most important reason for not working by 198 students out of 634 .

Table XIV indicatos that the five supplied statements for not working and "Other Reasons" were rated as first in importance 634 times. This number, 634, is representative of the number of times the six statements were rated as first in importance and does not represent the number of students. Several students omitted this question on the questionnaire completely, and others rated two of the statements first as being of equal importance.

"Cannot secure a suitable job". was rated 198 times as the most important reason for not working and "Need the time for school work", 178 times. "Financially necessary" became a significant roason for not working when it was rated first 117 times. A fow students, 35, gave "Parents will not permit" as their most important reason; and "Health will not permit" was certainly not a dociding factor for not participating in part-time employment, for only 4 of them rated this reason as first in importence.

"Other Reasons" added by the non-working students for not participating in part-time employment and the number of times added in all ratings were as follows:

\begin{tabular}{lc}
\hline Othor Reasons & Total No. Times Added \\
\hline Partioipation in athletics & 37 \\
Undor age & 28 \\
Too many other activitios & 13 \\
Work to do at home & 12 \\
Not onough time & 12 \\
No time for recreation & 7 \\
Did work, now laid off & 4 \\
Have not tried to find a job & 4 \\
Just don't & 3 \\
Live too far from town & 3 \\
\hline
\end{tabular}


Other Reasons (Continued)

Total No. Times Added

Too lazy

Do not know where to apply for work

Not enough benefit in part-time work

Part-time jobs are hard to find

No desire to work

Do not care to work yet

On leave of absence from a job

Not sure a job wanted

Just quit a job to prepare for college 1

Just quit a job, about to graduate 1

Do not go to the trouble to look for work I

Would like to work if grades were botter 1

Neod time for music

Neod time for band work

Job in sight, waiting for the oponing

Poor oyo-sight

3

2

2

2

1

1

1

1

1

i

Total:

143

Above is alist of 26 "Other Reasons" added by the non-working 143 times as a reason for not working. This number is representative of the frequency of appearance and not the number of times rated as first in importance.

This list indicates that a large number were not working because of participation in extra-curricular activities at school, such as participation in school athletics (37) and in the school band. Under age was checked 28 times. Work to do at home prevented 12 from working, and 12 felt that they did not "have time" to work. Indication for the need for vocational guidance and moans of placement were indicated by such answers as "Do not know where to find a job", "Part-time jobs hard to find", etc. Indifference and possible need for social adjustments were noted in such answers as "Too lazy", "No desire to work", "Not sure a job wanted", etc.

\section{Opinions of Part-time Work}

To determine attitudes of non-working students toward the participation of high school students in part-time employment, these two questions 
were asked; (1) "Do you think it wise for high school students to attempt to do part-time work?", and (2) "Hould you like to have a part-time job if you could find one that suited you?". These questions were answored by encircling "Yos", "No", or "Undicided".

(1) Advisability of High School Students Participating in Part-time Work

Table XV indicates the inswers of 662 non-working students to the first of the two questions mentionod above.

TABLE XV

Answers of 662 Non-Working Students

To the Question of

Advisability of Participation in Part-time Work

\begin{tabular}{llccc}
\hline \multirow{2}{*}{$\begin{array}{c}\text { School } \\
\text { Grade }\end{array}$} & \multicolumn{2}{c}{ No. Students Cheoking Answers } & Totals \\
\cline { 2 - 5 } & Yes & No & Undecided & \\
\hline Sophomore & 178 & 27 & 72 & 277 \\
Junior & 117 & 17 & 66 & 200 \\
Senior & 100 & 35 & 50 & 185 \\
& 395 & 79 & 188 & 662 \\
\hline
\end{tabular}

Read Tablo XV as follows: of 277 sophomores, 178 answered the question "Do you think it wise for high school students to work?" in the affirmativo; 27 said "no"; and 72 wore "undecided". Of 395 Students who answered the question "yes", 178 wero Sophomores, 117 were Juniors, and 100 were Seniors.

As indicated by Table XV: 395 , or about 59.7 per cent of the 662 non-working students who answered the question, thought that participation in part-time employment was advisable; 79 , or about 11.9 por cent though it unwise; and 188 , or bout 28.4 per cent were undecided on the question.

Soniors soemed least convinced of the advisability of participation of high school students in part-time employment with 100 , or about 54.1 por cent of the 185, answering the question "yes"; and 35, or about 18.9 
per cent, answering "no". Conviction gradually deoreased with advancement in school grades since 117 , or about 58.5 per cent of the Juniors, answered "yes"; and 17 , or about 8.5 per cent answered "no". Of the 277 Sophomores, 178, or about 64.1 per cent, answered "yos"; and 27, or about 9.8 per cent answered "no". Although this lack of conviction showed only slight increase from the Sophomoro to Senior yoar it was definite.

Indecision on the question was greatest among the Juniors since 66 , or about 33 per cent, were undecided. Seniors were second in indecision with 50, or about 27 per cent, answering the question "undecided". Sophomores showed the least indecision with 72 , or about 26.1 per cont, indicating that they were undecided on the question.

(2) Desires of Non-Working Students for Part-tine Job

Not only did a large per cent of the non-working students think that participation in part-time employment by high school students was advisable, but even a larger per cent indicated that they would like to have a part-time job if they could find one that suited them. Tablo XVI indicates the desires of these students for part-time employment.

\section{TABLE XVI}

Answers of 666 Non-Working Students to the Question "Would You Like to Have a Part-time Job?"

\begin{tabular}{|c|c|c|c|c|}
\hline \multirow{2}{*}{$\begin{array}{l}\text { School } \\
\text { Grado }\end{array}$} & \multicolumn{3}{|c|}{ No. Studonts Cheoking Answers } & \multirow{2}{*}{ Totals } \\
\hline & $\overline{\text { Y०8 }}$ & No & Undecided & \\
\hline Sophomore & 219 & 28 & 31 & $\overline{278}$ \\
\hline Juaior & 149 & 27 & 39 & 205 \\
\hline $\begin{array}{l}\text { Senior } \\
\text { Totals : }\end{array}$ & $\begin{array}{l}121 \\
489\end{array}$ & $\begin{array}{l}32 \\
87\end{array}$ & $\begin{array}{l}30 \\
90\end{array}$ & $\begin{array}{l}183 \\
666\end{array}$ \\
\hline
\end{tabular}


Read Tablo XVI as follows: of 278 Sophomores, 219 indicated that they would like to have a part-time job; 28 said "no" " and 31 were "undecided". Of the 489 who answered the question "no"; 219 were Sophomores, 149 were Juniors, and 121 were Seniors.

According to Table XVI: 489 , or about 73.4 per cent, of the 666 who answered the question, indicated that they would like to have a part-time job if they could find a suitable one; 87 , or about 13.7 por cont, did not want a part-time job; and 90 , or about 13.5 per cont, were undecided whether they wanted to work or not.

Similar to the first question, the interest of the non-working students in securing a part-time job decreased with advancoment in the school grades. Of the 183 Seniors, 121, or about 66.1 per cent, indicated that they would like to have a part-time job if they oould find one that suited them; and 32 , or about 17.5 per cont, answered the question "no". Of the 205 Juniors, 149, or about 72.7 per cent, answered the question "yes"; and 27, or about 13.2 per cent, said "no". Of 278 Sophomores, 219, or about 78.7 per cent, answered in the affirmative; and 28 , or about 10.1 por cent, answered negatively. Again, lack of desire for part-time employment decreased with advancement in the school grades, but only slightly.

Indecision on this question, however, showed constant increase with advancement in sohool grades. Of the Sophomores, 31, or about 11.2 per cent, were undecided on the question as compared to 29 , or about 14.1 per cent, of the Juniors and 30 , or about 16.4 per cent of the Seniors. This may have been due to the fact that the Seniors were concentrating their efforts on finishing 8 chool.

\section{E. Summary}

In regard to the non-working student and his attitude toward 
the participation of high school students in part-time employment and toward socuring such omployment for himself, the following is a summary of the information compiled in the foregoing sections of this chaptor.

1) Of the 1055 studonts at Male High School who took part in this survey, 683 , or about 64.7 per cent, were classed as "non-working" since they were not actively engaged in a part-time job for pay.

2) The age-range of this group was from 14 to 22 years. Of the 683, 232, or about 33.9 per cent, were under the age of 16 . The 16 to 17-year-old group comprised the largest number of students with 392, or about 57.4 per cent in this group. Only 81 , or about 11.8 per cent, were in the 18 to 19-year-old group; and only 8 , or 1.2 per cent, were over the age of 19.

3) The most prominent reasons givon for not working by the nonworking students wero the inability to find "suitable" job, and the feeling that the time was needed for school work. Of the 634 times the five supplied statements and "Other Reasons" were checked as the most important reason for not working, 198 were for the former reason and 178 the latter. "Financially not necessary" was next most frequently checked as most important - 117 times out of 634 . Health and the objection of parents had, according to the students, rery little to do with their not working. These were checked 4 and 35 times respectively most important.

"Other Reasons" given by the students indicated that participation in school activitios, underage, and indifference played important roles in the non-participation in part-time employment.

4) Of the 662 non-working students who answered the question 
"Do you think it wise for high school students to attempt to do parttime work?", 395, or about 59.7 per cent, answered "yos". Seventynine, or about 11.9 per cent, thought it unwise while 188, or about 28.4 per cent, were "undecided" on the question. Seniors were less convinced of the advisability of high school students participating in part-time employment with only 54.1 per cent answering the question in the affirmative as compared to 58.5 per cent of the Juniors and 64.1 per cent of the Sophomores.

5) Even a larger per cent of the non-working students indicated that they would like to have a part-time job if they could find one that was suitable to them. This opinion was expressed by about 73.4 per cent of the 666 students who answered this question.

The desire of students for part-time employment decreased with advancement in the school grades. This was indicated by the fact that 66.1 per cont of the Seniors, 72.7 per cent of the Juniors, and 78.7 per cent of the Sophomores answered the question in the affirmative. 


\section{CHAPTER V}

\section{A COMPARISON OF}

WORKING AND NON-WORKING STUDENTS

Distinotion between the working and non-working students was made in preceding chapters. Working students were considered as those who were actively engaged in part-time employment for pay; all others were classed as non-working. Chapter III was a compilation of information and data on the working group and Chapter IV was devoted to the non-working students.

Frequently, working and non-working students are considered, without conclusive information, to be quite different in respect to age, scholastic attainment, and other factors common to both groups. To determine the authenticity of this contention, this chapter makes a comparison of these two groups of students at Male High School in respect to such common factors as (1) age, (2) scholastic attainment, (3) plans for the future, (4) views on educational value of part-time work, (5) views on vocational guidance, and (6) the use of incomes. Arrival at decisive conclusions on the difference, or lack of differences, in the working and non-working students was the objective of this comparison. Such conclusions would be helpful in determining the need for a work-experience program, the extent of such a program, or the need of students for more guidance in choosing an ocoupation, preparing for it, entering upon and progressing in it. 1

$$
\text { A. Ages }
$$

The ages of working and non-working students have been previously

1. Myers, George E., Principals and Techniques of Vocational Guidance, p. 3 . 
discussed in Chapters III and IV respectively. These data are now brought together in Table XVII for comparison.

\section{TABLE XVII}

An Age Comparison of

Working and Non-Working Students

by Per Cents of the Total

Number in Each Group

\begin{tabular}{|c|c|c|c|c|c|}
\hline \multirow[t]{2}{*}{ Classification } & \multirow[t]{2}{*}{$\begin{array}{l}\text { Total } \\
\text { Number }\end{array}$} & \multicolumn{2}{|c|}{$\%$ in Certain Age } & \multicolumn{2}{|l|}{ Groups } \\
\hline & & Under 16 & $16-17$ & $18-19$ & Over 19 \\
\hline $\begin{array}{l}\text { Working } \\
\text { Non-Working }\end{array}$ & $\begin{array}{l}372 \\
683\end{array}$ & $\begin{array}{r}9.9 \\
29.6\end{array}$ & $\begin{array}{l}72.3 \\
57.4\end{array}$ & $\begin{array}{l}17.0 \\
11.8\end{array}$ & $\begin{array}{l}0.8 \\
1.2\end{array}$ \\
\hline
\end{tabular}

Read Table XVII as follows: Of 372 working students, 9.9 per cent were under 16 years of age; 72.3 per cent were from 18 to 17 ; 17 per cent were from 18 to 19; and 0.8 pdr cent were over 19 .

Table XVII indicates a very definite difference in the per cent of the working and non-working students who were under the age of 16 years. Of 372 working students, only 9.9 per cent were under 16 as compared to 29.6 per cent of the non-working. A very definite difference is indicated, also, in the 16 to 17-year-old group with 72.3 per cent of the working students as compared to 57.4 per cent of the non-working students in this age-group. A much less appreciable difference is evident in the 18 to 19-year-old group with 17 per cent of the working and 11.8 per cent of the non-working in this agegroup. Finally, a slightly larger per cent of the non-working students ( 1.2 per cent) were over 19 then were working students ( 0.8 per cent).

The most gratifying of the findings of this age comparison was the small number of working students who were under the age of 16; 
indicating that exploitation of high school students relative to age is negligible. This fact is even less significant since Kentucky Labor Laws allow the issuance of work-permits to 8 ome children under the age of 16 under certain conditions. Gratifying, also, is the insigniflcant difference in the per cent of working and nonworking students who were over the normal age for high school students. This fact indicates that age maladjustments, if at all evident, are no more prominent in the working group of students than in the non-working group.

\section{B. Scholastic Attainment}

Tables XVIII and XIX indicate the average grades of working and non-working students at Male High School. This information was obtained from student answers to the questionnaire and not from actual records. The writer, therefore, realizes that these grades may not be absolutely free from inaccuracies, but he believes that they are sufficient for the purposes of this study.

TABLE XVIII

Scholastic Attainment of Working Students

\begin{tabular}{|c|c|c|c|c|c|c|}
\hline \multirow{2}{*}{$\begin{array}{l}\text { School } \\
\text { Grades }\end{array}$} & \multicolumn{5}{|c|}{ Grades and Number of Students } & \multirow{2}{*}{ Totals } \\
\hline & A & B & C & D & $\mathbf{E}$ & \\
\hline Sophomore & 0 & 9 & 45 & 32 & 5 & 91 \\
\hline Junior & 1 & 18 & 93 & 31 & 0 & 143 \\
\hline Senior & 1 & 14 & 92 & 31 & 0 & 138 \\
\hline Totals: & 2 & 41 & 230 & 94 & 5 & 372 \\
\hline Per cents: & 0.6 & 11.0 & 61.8 & 25.3 & 1.3 & 100.0 \\
\hline
\end{tabular}

Read Tables XVIII and XIX as follows: In Table XIX; of the 285 non-working Sophomores 3 had and "A" average, 44 had a "B", 148 had a "C", 81 hed a "D", and 9 had an " $\mathrm{E}$ ". Of the 683 non-working students, 3 Sophomores, 3 Juniors, and 3 Seniors (a total of 9 or 1.3 per cent) had an "A" average. 
TABLE XIX

Scholastic Attainment of Non-Working Students

\begin{tabular}{|c|c|c|c|c|c|c|}
\hline \multirow{2}{*}{$\begin{array}{l}\text { School } \\
\text { Grades }\end{array}$} & \multicolumn{5}{|c|}{ Grades and Number of Students } & \multirow{2}{*}{ Totals } \\
\hline & A & B & $\mathrm{C}$ & D & $\mathbf{E}$ & \\
\hline Sophomore & 3 & 44 & 148 & 81 & 9 & 285 \\
\hline Junior & 3 & 33 & 131 & 46 & 0 & 213 \\
\hline Senior & 3 & 34 & 116 & 32 & 0 & 185 \\
\hline Totals: & 9 & 111 & 395 & 159 & 9 & 683 \\
\hline Por cents: & 1.3 & 16.3 & 57.8 & 23.3 & 1.3 & 100.0 \\
\hline
\end{tabular}

In comparing Tables XVIII and XIX, no outstanding differences in scholastic attainment between the working and non-working students were found. The mode for each was the grade "C" which included 61.8 per cent of the working group as compared to 57.8 per cent of the nonworking. The per cent of students in eech group who had an average grade of "E" (failing) was 1.3 per cent of the total of each. A slight difference in "A" students was noted with 1.3 per cent of the nonworking and 0.6 per cent of the working students in this grade average. The per cent of working students with a "B" average was 16.3 per cent as compared to 11 per cent of the other group. The per cent of students with a "D" average was only slightly greater in the working group 25.3 per cent as compared to 23.3 per cent of the non-working. Aocording to this information, then, participation in part-time employment had little or no effect upon the scholastic attainment of working students at Hale High School. The survey made by the National Chiled Labor Committee of Wartime Work-Experience Programs in eleven communities in the United States revealed similar effects. This survey found that 93 per cont of 2414 who were employed in part-time jobs, 
"thought that participation in work had had oither no offect or a favorable effect on scholarship."I This is comparable, also, to the opinions of 78.3 per cent of the 372 working students at Male High School as expressed in this study that participation in part-time work had not hindered their school work in any way (See Table $\mathrm{X}$, Chapter III).

\section{Plans for the Future}

Included in the study of the plans of the students at Male High School for the future were (1) plans for further education, and (2) vocational plans. A comparison of the plans of the working and nonworking students for the future according to these two aspects is the purpose of this section of this chapter.

(1) Plans for Furthor Education

Both the working and non-working students were asked to answer the questions "Do you plan to finish high school?", and "Do you plan to go to college?" by encircling "yes", "no", or lundecided".

Tables XX and XXI indicate the answers of the working and nonworking students, respectively, to the first of these two questions and the number and per cent of each group who gave each of the three answers.

TABLE XX

Number and Per cont of Working Students Planning to Finish High School

\begin{tabular}{crrrrrrrr}
\hline $\begin{array}{l}\text { Answers } \\
\text { to the } \\
\text { question }\end{array}$ & \multicolumn{2}{c}{ Sophomore } & \multicolumn{2}{c}{ Junior } & \multicolumn{2}{c}{ Senior } & \multicolumn{2}{c}{ Totals } \\
\cline { 2 - 9 } & $\overline{\bar{N} 0}$ & $\%$ & No. & $\%$ & No. & $\%$ & No. & $\%$ \\
\hline Yes & 84 & 92.3 & 138 & 96.6 & 136 & 98.6 & 358 & 96.2 \\
No & 1 & 1.1 & 2 & 1.3 & 1 & 0.7 & 4 & 1.1 \\
Undecidod & 6 & 6.6 & 3 & 2.1 & 1 & 0.7 & 10 & 2.7 \\
Totals: & 91 & 100.0 & 143 & 100.0 & 138 & 100.0 & 372 & 100.0 \\
\hline
\end{tabular}


TABLE XXI

Number and Per-cent of

Non-Working Students Planning to

Finish High School

\begin{tabular}{|c|c|c|c|c|c|c|c|c|}
\hline \multirow{2}{*}{$\begin{array}{l}\text { Answers } \\
\text { to the } \\
\text { Question }\end{array}$} & \multicolumn{2}{|c|}{ Sophomore } & \multicolumn{2}{|c|}{ Junior } & \multicolumn{2}{|c|}{ Senior } & \multicolumn{2}{|c|}{ Totals } \\
\hline & No. & $\%$ & No. & $\%$ & No. & $\%$ & No. & $\%$ \\
\hline $\begin{array}{l}\text { Yes } \\
\text { No } \\
\text { Jndecided } \\
\text { Totols : }\end{array}$ & $\begin{array}{r}276 \\
1 \\
8 \\
285^{8}\end{array}$ & $\begin{array}{r}96.8 \\
.4 \\
2.8 \\
100.0\end{array}$ & $\begin{array}{r}209 \\
0 \\
4 \\
213\end{array}$ & $\begin{array}{r}98.1 \\
.0 \\
1.9 \\
100 \quad .0\end{array}$ & $\begin{array}{r}185 \\
0 \\
0 \\
185\end{array}$ & $\begin{array}{r}100.0 \\
.0 \\
.0 \\
100.0\end{array}$ & $\begin{array}{r}671 \\
1 \\
12 \\
683\end{array}$ & $\begin{array}{r}98.3 \\
.1 \\
1.6 \\
100.0\end{array}$ \\
\hline
\end{tabular}

Read Tables XX and XXI as Follows: In Table XXI: 276 , or 98.8 por cent of the non-working Sophomores plan to finish high school; one, or 0.4 per cont said "no"; and 8 , or 2.8 per cent were "undecided". Under "Totals": 671, or 98.3 per cent of 681 said "yes"; ono, or 0.1 per cont said "no"; and 12 , or 1.6 per cent wore "undeoided".

According to Tobles $X X$ and $X X I: 98.3$ per cent of 211 the nonworking students plan to finish high school as compared to 96.2 per cent of the working group; 0.1 per cent of the non-working group said "no" as compared to 1.1 percent of the working group; and 1.6 per cent of the non-working were "undecided" about finishing high school as compared to 2.7 per cent of the working group. In both cases, the per cent of the students who indicated that they did plan to finish high school increased with advancement in the school grades and, similarly, indecision decreased.

These tables indicate, therefore, that 2.1 per cent more of the non-working students plan to finish high school than do the working students; and that one per cent less indicated the intertion of not finishing. Participation in part-time work does not, therefore, seem to encourage the desire for termination of school; to the contrary, it seems possible that part-time work might have influenced working students to stay in high school until graduation. 
Tables XXII and XXIII indicate the answers given by the working and non-working students to the question "Do you plan to go to college?". This question was, also, answered by encircling "yes", "no", and "undocided".

\section{TABLE XXII}

Number and Per cent of Working Students Who Planned to Go to College

\begin{tabular}{crrrrrrrrr}
\hline $\begin{array}{l}\text { Answers } \\
\text { to the } \\
\text { Questions }\end{array}$ & \multicolumn{2}{l}{ Sophomore } & \multicolumn{2}{l}{ Junior } & \multicolumn{2}{c}{ Sonior } & \multicolumn{2}{c}{ Totgls } \\
\cline { 2 - 9 } & No. & $\%$ & No. & $\%$ & No. & $\%$ & No. & $\%$ \\
\hline Yes & 38 & 41.8 & 90 & 62.9 & 97 & 70.3 & 225 & 60.5 \\
No & 22 & 24.2 & 24 & 16.8 & 20 & 14.5 & 65 & 17.7 \\
Undecided & 31 & 34.0 & 29 & 20.3 & 21 & 15.8 & 81 & 41.8 \\
Totals : & 91 & 100.0 & 143 & 100.0 & 138 & 100.0 & 372 & 100.0 \\
\hline
\end{tabular}

TABLE XXIII

Number and Por cent of Non-Working Students Who Flanned to Go to College

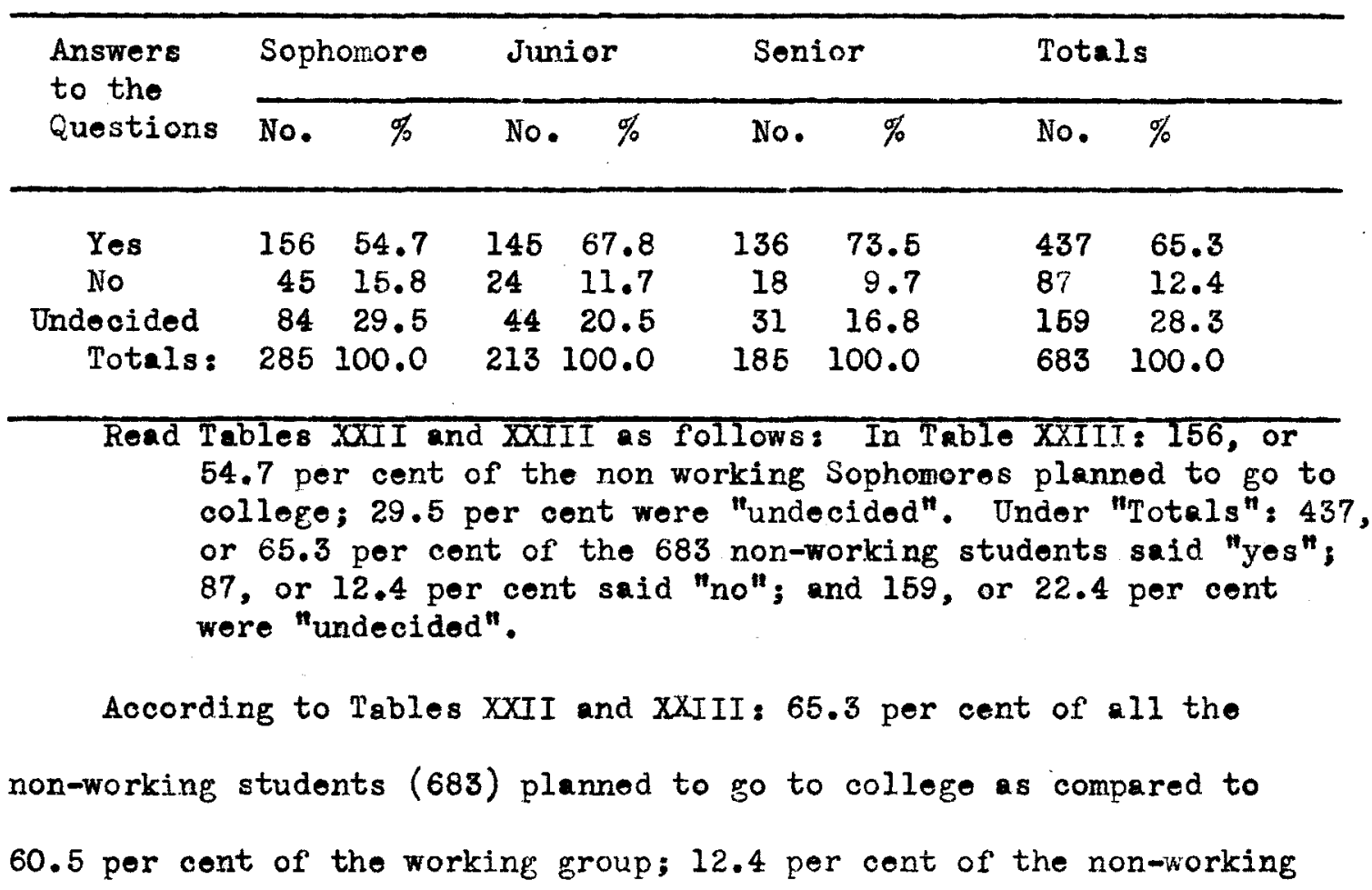


said "no" as compared to 17.7 per cent of the working; and 22.3 per cont of the nonoworking were "undecided" as compared to 21.8 per-cent of the working group.

The large per cent of both groups who planned to go to college might seem surprising, but it may be recalled that Male High School prides itself in its preparation of students for college. The fact that the per cent who are planning to enter college increased with advancement in the school grades is not surprising ej.ther. Dr. Hilda Threlkeld, in her study of the vocational and oducational plans of 3884 collegeiseniors, found that 43.8 per cent of the group upon answering the question "When did you decide definitely to go to college?" indicated their senior year in high school; 13.2 per cent indicated the junior year; and $7: 5$ per cent indicated the sophomore year. ${ }^{1}$ She explained this by saying that "the completion of the high school course necessitates a decision." The increase in the por cent of the students having made a decision to enter High School, then, seems due to a feeling of necessity as the end of the high school course drow nearer. These two tables indicate, also, that less than 5 per cent more of the 'non-working students planned to enter college than did working students. Such decisions by the working students, therefore, do not seem to have been influenced by their participation in part-time work.

\section{(2) Vocational Flans}

Tables XXIV and XXV indicate the per cent of the working and nonworking students at Male High School who had made vocational choices. 
TABLE XXIV

Number and Per cent of Working Students Who had Made Vocational Choices

\begin{tabular}{llrrrrrrrr}
\hline $\begin{array}{l}\text { Answers } \\
\text { to the } \\
\text { Questions }\end{array}$ & \multicolumn{2}{l}{ Sophomore } & \multicolumn{2}{c}{ Junior } & \multicolumn{2}{c}{ Senior } & \multicolumn{2}{l}{ Totals } \\
\cline { 2 - 10 } & No. & $\%$ & No. & $\%$ & No. & $\%$ & No. & $\%$ \\
\hline Yos & 29 & 31.9 & 69 & 48.3 & 76 & 55.0 & 174 & 46.8 \\
No & 22 & 24.2 & 31 & 21.7 & 22 & 16.0 & 75 & 20.2 \\
$\begin{array}{c}\text { Undecided } \\
\text { Totals: }\end{array}$ & 40 & 43.9 & & 48 & 30.0 & 40 & 29.0 & 123 & 33.0 \\
& 91 & 100.0 & 143 & 100.0 & 138 & 100.0 & 372 & 100.0 \\
\hline
\end{tabular}

TABLE XXV

Number and Per cent of Non-Working Students Who had Made Vocational Choices

\begin{tabular}{lrrrrrrrrr}
\hline $\begin{array}{l}\text { Answers } \\
\text { to the } \\
\text { Questions }\end{array}$ & \multicolumn{2}{l}{ Sophomore } & \multicolumn{2}{l}{ Junior } & \multicolumn{2}{l}{ Senior } & \multicolumn{2}{l}{ Totals } \\
& No. & $\%$ & No. & $\%$ & No. & $\%$ & No. & $\%$ \\
\hline Yos & 102 & 35.8 & 85 & 39.7 & 74 & 40.0 & 261 & 38.5 \\
No & 82 & 28.8 & 46 & 21.5 & 39 & 21.0 & 166 & 23.7 \\
Undecided & 101 & 35.4 & 83 & 38.8 & 72 & 39.0 & 256 & 37.8 \\
Totals: & 285 & 100.0 & 213 & 100.0 & 185 & 100.0 & 683 & 100.0 \\
\end{tabular}

Read Tables XXIV and XXV as follows In Table XXV: 102 , or 35.8 per cent of the non-working Sophomores, indicated a definite vocational choice; 82 , or 28.8 por cent, said "no"; and 101 , or 35.4 per cent, were "undecided". Under "Totals": 261, or 38.5 per cent of the 683, had made a definito choico; 166, or 23.7 per cent, said "no"; and 256 , or 37.8 per cent, were "undecided".

Tables XXV and XXVI indicate findings comparable to those of Dr. Threlkeld's in which 31.8 per cent of the college seniors questioned in her survey indicated that they had made their vocational choice "sometime prior to or during high school: The above tables indicate that 46.8 per cent of all the working students and 38.5 pet cont of the non1. Threlkeld, op. cit., p. 47 . 
working students at Male High School had mado definite vocational choice. Again it will be noticed that the per cent of those who had made vocational choices increased with the advancement in the school grades.

To the writer, the fact that 8.3 per cent more of the working students than non-working students had made a definite vocational choice is significant. This seems to indicate that port-time employment tends to aid in the making of a rocational choice.

\section{Views on Educational Value of Part-time Work}

All students at Male High School, working and non-working, wore asked the question "Do you think that a part-time job has any educational value for high school students?" Table XXVI is a compilation of the opinions of both groups on this question.

TABLE XXVI

Opinions of Working and Non-Working Students on the Educational Value of Part-time Work

\begin{tabular}{|c|c|}
\hline \multirow{2}{*}{$\begin{array}{l}\text { Answers } \\
\text { to the } \\
\text { Question }\end{array}$} & Working Studonts \\
\hline & Number Per cent \\
\hline $\begin{array}{c}\text { Yes } \\
N_{0} \\
\text { Undecided } \\
\text { Totals: }\end{array}$ & $\begin{array}{rr}336 & 90.4 \\
18 & 4.8 \\
18 & 4.8 \\
372 & 100.0\end{array}$ \\
\hline \multicolumn{2}{|c|}{$\begin{array}{l}\text { Read Table XXVI as follows: of } 372 \text { working students, } 336 \text {, or } \\
90.4 \text { per cent, thought part-time work was of oducational } \\
\text { value; } 18 \text {, or } 4.8 \text { per cent, said "No"; and } 18 \text {, or } 4.8 \text { per cent, } \\
\text { were undecided. }\end{array}$} \\
\hline \multicolumn{2}{|c|}{ According to Table XXVI, 90.4 per cent of the working students, } \\
\hline
\end{tabular}


a difference of 16.3 per cont, but the per cent of both groups holding this opinion seems sufficiently high to create real concern on the part of high school administrators toward giving some consideration to the inclusion of some sort of work-experience program in the school curriculum. The relatively low per cent of both groups ( 4.8 per cent of the working students and 9.3 per cent of the non-working) who gave negative answers to the question adds even more significance to the question.

It soems probable that participation in work-experience program might be instrumental in making the above opinions of high school students more realistic. Eighty $p \in r$ cent of 2,000 students who wore participating in work-oxperionce programs reposted upon by the National Child Labor Committee indicated satisfaction with such programs, and recommended them to other students. ${ }^{l}$ One of the reasons given for their recommendation was that work-exporience programs gave "more reality to school".

\section{E. Views on Vocational Guidance}

Often the expressed desires and needs of students have been valuable factors in curriculum development. With this though in mind, the writer sought to gather information on the expressed desires and needs of students at Malo High School concerning such aspects of vocational guidance as (1) the need for more vocational guidance: (2) the relation of courses in vocational guidance to traditional subject matter; and ( 3 ) the need for a job placement service.

1. Elicker, 으. cit., p. 23 . 
(1) The Need for More Vocational Guidance

To gather information on the first of these three phases of vocational guidance, the question "Do you think that the school should do more to educate its students concerning the nature of various occupations and professions in order that the student might choose his career more wisely?" was asked of both working and non-working students. Compilation of answers showed very little difforence in the opinions of the two groups concerning the question. Rosults of this compilation of answers show that 88 per cent of the working students and 82 per cent of the non-working felt that more vocational guidance should be provided by the school as a part of its curriculum. Only 3.5 per cont of the working group and 6.6 per cent of the non-working gave nogative answers to the question while 8.3 per cent of the former group and 11.4 per cent of the latter indicated that they were undecided on the question.

Quite a large per cent of all the students at Male High School, therefore, felt that the school should do more toward the provision of guidance in vocational choice. This opinion was almost equally shared by both the working and non-working students.

(2) Relation of Vocational Guidance Courses To Traditional Subject Matter

In comparison to the number of students who felt that the school should provide more voca ional guidance, the number who felt that this phase of the school curriculum was equal in importance to traditional subject matter was rolatively small. Answers to a question relative to this contention revealed that 51.2 per cont of the non-working students and 62 per cent of the working felt that vocationel guidance courses and traditional subject matter were of equal importance. Negative 
answers on this question were considerably higher than those on the first question concerning vocational guidance. On this question 30.2 per cent of the non-working and 20.4 per cent of the working students felt that vocational guidance was not oqual in importance to tradidional subject matter while 18.6 per cent of the former group and 17.4 per cent of the latter were undecided.

Although the number of affirmative answers on this question was relatively low as compared to the one concerning the need for more vocational guidance, this percentage seems more significant when viewed from the angle that Male Aigh School is of a college preparatory nature and that a large per cont of the students indicated their intention to go to college as well as a large per cent who indicated that they had already made a vocational choice. The working group, however, seemed more inclined to feel that vocational guidance was equal in importance to traditional subject matter than were the non-working group. Almost 11 per cent more of the working group answered the question affirmetively than did the other group.

(3) The Need for a Job Placement Service

The National Child Labor Committee, in concluding its report on Wartime Work-Experience Programs, recognized the fact that students gain some valuable experience in finding their own jobs but felt $t$ at, in the interest of placing them in jobs suitable to their interest and abilities, and to insure protection against exploitation, a part-time job placement service should be offered to them. ${ }^{1}$ The study made by the United States Office of Education on School-and-Work Programs in

1. Elicker, 100. cit., pp. 29-30. 
136 school systoms found that many schools had some form of part-time job placement service and, where found, that it was popular with both employers and students seeking work. I This study found the United States Employment Service was providiag branches in many of the high schools for placement and follow-up, but that in many instances the "school placement office offered the only specialized service for students wanting part-time jobs". It was also rovealed that, in most instances, young people did not make much use of public employment services made available to everyone in the cominunity. In the conclusion of this report, wise placement of students in part-time jobs was recommended so as to insure real loarning value and the best opssible working conditions.2

In this study made at Male High School, all students wero asked "ivould a part-time placement (employment) bureau, where high school students could apply for part-time work and be placed in jobs according to their interests, abilities, otc. be worthwhile organization?". Compilation of the answers to this question showed that 92.5 per cent of the working students, and 89.8 per cent of the non-working thought that such a service would be a worthwhile organization. Approximately 3 per cent of each group felt that such an organization would not be worthwhile; and only 4.6 per cent of the working group and 7 per cent of the non-working indicated indecision on the question.

That a placement service for part-time jobs would be wortinhile was, therofore, highly epproved by the majority of both working and non-working students at Hiale High School. 'l'he school does have one teacher, however, who takes the responsibility of accepting the nemes of students who

1. U. S. Office of Education, op. cit., pp. 22-23. 2. Ibid, , pp. 50-52. 
desire part-time work and makes recommendations to employers who, perchance, contact the school desiring the services of a student for part-time work or, in some cases, for the services of graduating seniors for full-time employment. Inextonding oven this limited service to its students, however, Hale High Sohool is probably doing more than most high schools since it is probable that "not more than 3 per cent of the school systems of 10,000 or more have employed full-time, woll qualified personnel to provide placement service". 1

\section{F. How Students Use their Income}

The National Child Labor Committee found that many of the schools included in tis study of work-experionce prograns were providing counsel of the wise use of money.2 The most frequent uses made of money earned by 1482 students in two cities was for contributing to home expenses, spending money, savings accounts, clothers, and purchase of war bonds and stamps - in approxime tely that order.

Prompted by the above study, the writer decided that both working and non-working, might prove interesting. They were, therefore, all asked the question "what do you do with your incone?" A list of six statements relative to the question was supplied, and the students.were asked to heck those which appliod to their own case and a blank was provided for addition of any other statement not included. Table XXVII is a compilation of the nupiber of times oach of these statements wore checked by the working and non-working students.

\section{TABLE XXXII}

How Students Use Their Income The Number of Times Each Statement was Checked by Working and Non-Working Students

1. American Association of school Administrators, $\mathrm{Sco01s}$ and Manpower, p. 223.

2. Elicker, loc. cit., p. 23. 


\begin{tabular}{lcc}
\hline Statements on the Use & Number Students Chocking \\
Incomes & $\begin{array}{c}\text { Each Item of Exponditure } \\
\text { iorking } \\
\text { Students }\end{array}$ & $\begin{array}{c}\text { Non-Working } \\
\text { Students }\end{array}$ \\
\hline Recreation and Fun & 270 & 554 \\
Necessities (Food, Clothing, & 167 & 243 \\
Books, etc) & 141 & 139 \\
Bank Account & 133 & 302 \\
Church and Charities & & 122 \\
Savings Bonds, or other & 69 & 18 \\
Investments & 35 & 27 \\
Help to Support Fomily & 22 & 1405 \\
nother Statements & & \\
Total Times all Statements: & &
\end{tabular}

Read Table XXVII as follows: The statement of the use of income "Recreation and Fun", was checked 270 times by working students and 554 times by non-working students. All the statements were checked a total of 844 times by the working students and 1405 times by the non-working.

According to Table XXVII, "Recreation and Fun" was the most frequently ohecked item of expenditure by both the working and nonworking students. This statement was checked 554 time, or 32.3 per cent of the 1405 times that all the items were checked by the non-working group; and 270 times, or 31.9 per cent of the 844 times th $t$ all the items were chocked by working students. The statement which rated second with the non-working students wias "Church and Charities" which was checked 302 times, or 21.4 per cent of the total. Ihis item rated fourth with the working students and was checked 133 times, or 15.7 por cent of the total. "Necessities" ranked second with the working students, being checked 167 times, or 19.7 per cent of the 844 . The non-working students ehose this item 243 times out of the 1405 times, or 17.3 per cent; thus, making it their third oroice. The third choice of the working students was the item, "Bank Accounts", which was checked 141 times, or 16.7 per cent, of the total. This expenditure was fourth among all the statements checked by the non-working students, being 
checked 139 times, or 9.8 per cent of the total.

The first four of the items in Table XXVII received 84.2 per cent of the total checks made by the working students and 88 per cent of the total made by the non-working students. "Savings Bonds, and

Investments" received 8.6 per cent of the checks made by the non-working; and 8.2 por cont of the chooks made by the working students. "Help to support the Family", the statement which ranked the lowest in number of tinies checked by both groups, received only 4.1 per cent of the total checks made by the working students and 1.1 per cent of those made by the non-working.

"Other Statements" were made 7 times by the working students and 9 times by the non-working. These statements and the number of times oach was chocked were as follows:

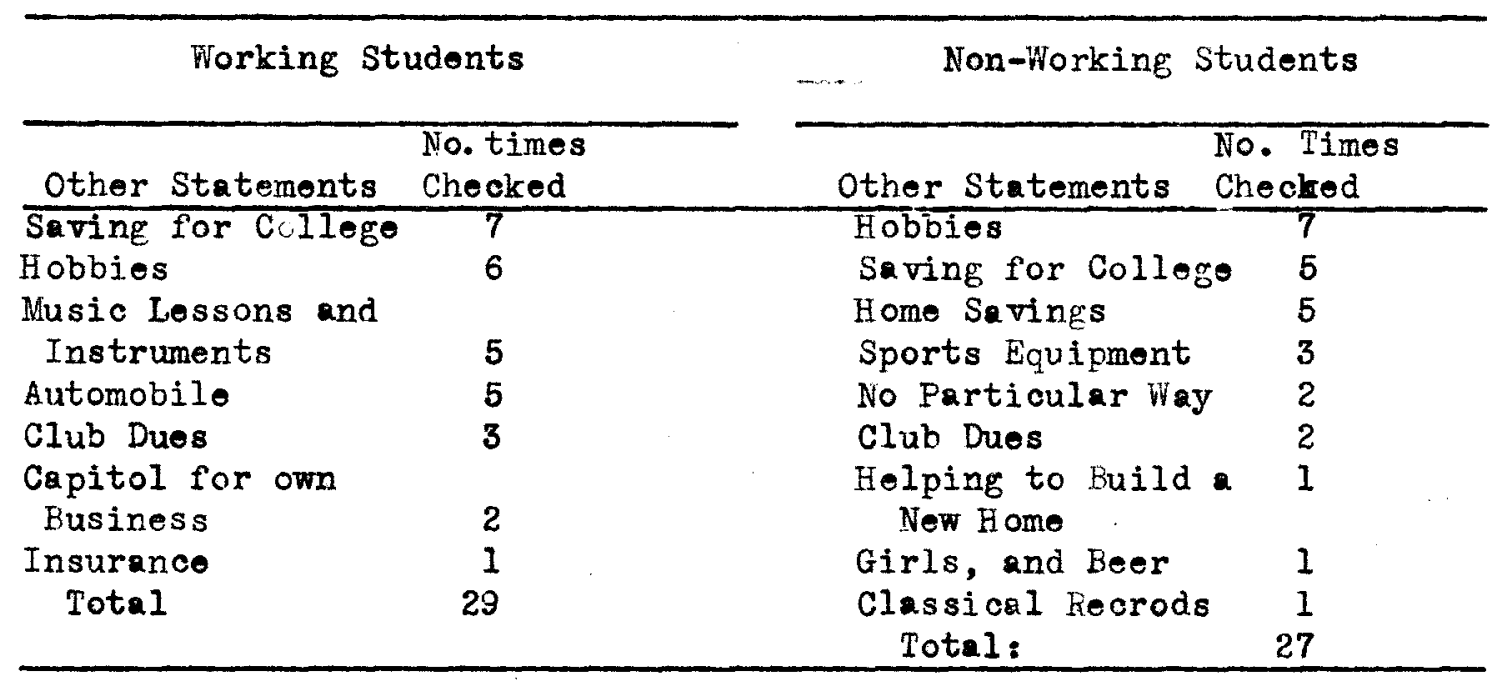

The most interesting thing noted about "Other Statements" was that "Saving for College" and "Hobbies" were the two most frequently added statements by both groups. Interesting, also, was the fact thet two of the working students wer using part of their income as capital in their own businesses. "No Particular Way" and "Girls and Beer" wero the only indications of insincerity noted on this question. Both statements were made by non-working students. 


$$
\text { G. Summary of Chapter }
$$

The purpose of this chapter was to deternine the authenticity of the usual contention that working and non-working students differ considerably in respect to age, scholastic attainment, and other factors cormon to both groups. This purpsoe was attempted through a comparison of these two groups at Wale High School. Summary of the results of this comparison is as follows:

11. Very definite differences were found in the number of students under the age of 16 years and the number of students between the ages of 16 to 17 years. There was on $y 9.9$ per cent of the working students under 16 years of age as compared to 29.6 per cent of the non-working students; and there was 72.3 per cent of the working students between the ages of 16 and 17 as compared to only 57.4 per cent of the nonworking students. No significant differences were found in the number of each group in age groups over 17 years.

2) No outstanding di ferences were noted relative to scholastic attainment. The mode for each groupwas an average grade of "C" with 61.8 per cent of the working students, and 57.8 per cent of the non-working with this average. The number of students with an "A" averago was only slightly greater in the non-working group than in the working. Oppositely, only a slightly larger number of working students had a "D" average than the non-working.

3) Rolative to plans for the future, no a preciable diff rence was found in the number of students planning to finish high school with 98.3 per cent of the non-working, 96.2 per cent of the working students indicating plans in this direction.

The number of students who were planning to go to college as high, but no significant difference ns noted botween the wo groups of 
students. Sixty-five and three-tenths per cent of the non-working planned to enter college as compared to 60.5 por cent of the working group.

Information on the number of students who had made vocational choices showed that 46.8 per cent of the working, and 38.5 per cent of of the non-working group said they had made difinite choices. As indicated by this information, 8.3 per cent more of the working than the non-working students indicated such choices.

4) Opinions of students on the educational value of part-time work revealed that 90.4 per cent of the working group, as compared to 74.1 per cont of the non-working, felt that part-time work does have educational value. This indicates that 16.3 per cent more working students hold this opinion than did non-working students.

5) Working and non-working students shared the opinion that the school could do more in the way of providing vocational guidance than it was doing. Eight-eight per cent of the working students end 82 per cent the non-working indicated this opinion.

6) Sixty-two per cent of tho working group felt that courses in vocational guidance were equal ininportance to the traditional subjects as compared to 51.2 per cent of the non-working group - a difference of 10.8 per cent.

7) Both groups of students were much in favor of a part-time job placement service with 92.5 per cent of the working students and 89.8 per cent of the non-working students expressing this opinion.

8) No significant difference was indiceted in the was working and non-working students used their income. the most frequent expenditures indicated by both groups wer for recreation and fun, necessities, bank accounts, and church and charities. 
CHAPTER VI

CONCLUSTONS AND RECONHENDATIONS

The results of this study of part-time and non-working students at Louisville Male High School were, in the opinion of the writer, convincingly in favor of work-experience as a part of the "total education" of high school youth. He feels that no longer should a part-time job be considered hindrance to the school work of those who participate. To the contrary, it should be considered of constructive value to school work and as highly desirable in the "indoctrination of youth in the democratic way of life" and as a valuable means of "bridging the gap between school and employment".

As a basis for this cutention, the witer now presents the conclusions of the separate studies on (1) the working students, (2) the non-working students, and ( 3 ) a comparison of factors common to both groups.

\section{A. The horking Students}

The working student was the primary concern of this complete study. A summary of the conclusions of this phase of the study are as follows :

1) A sufficient number of the students at Male High School was participating in part-time employment ( 35.3 per cent of the 1055 studied) to warrant the special interest of the school.

2) Very little, or practically no evidence of serious exploitation relatize to age, hours worked, or wges earned was noted in this study.

3) Working students liked their jobs, but a large per cent of them did not fecl that they would care to male tre type of work in $-93--$ 
which they wore now engaged their rocational choice for the future.

4) Working students participated in part-time employment because they liked to feel self-sufficient, because they felt that it was good training, and because of their desire to earn spendir. money.

5) Working students did not feel that their part-time job was a hindrance to their shool work. In fact, a very large per cent of them felt that their job had incresed interest in school and in securing an oducotion.

\section{B. The Non-Working Students}

The following conclusions are based upon the opinions of the non-working students relative to work-experience:

1) Those students who were not engaged in part-time employment were not employed, according to their statements, because they could not find a suitable job, or because they did not $t^{2} \in \mathbb{l}$ it financially necessary to work. A fow indicated that they needed the time for their sbhool work.

2) Bad health and parent opposition had only an insignificant effect upon the participation of these youth in part-time work.

3) More than half of the non-working students felt that it was not unwise for high school students to participate in part-time employment. Only 12 per cent thought it unwise while 28 por cent were undecided on the question.

4) A large majority ( 73.4 per cent) of the non-working students would like to have a part-time job if they could lind one that was suitable to their interests and bilities.

\section{A Comparison of horking and Non-Working Students}

The following conclusions resluted from the comparison of some 
factors common to both groups of students:

1) Very little difference in age was noted between the two groups of students except in the number of each under the age of sixteen yeers. A much larger per cent of the non-working group was under this age than was true of the other groupwwich indicates a lack of exploitation relative to age of high school students in this school.

2) Contrary to general opinion, part-time work did not make any appreciable difference in the scholastic attainment of the two groups with the non-working having only a slightly better average.

3) The number of each group who planned to finish high school was high, but no perticular difference was noted botween them, with 98.3 per cent of the non-working and 96.3 por cent of the working group answering the question in the affirmative.

4) Similarly, no great difference was noted between the two groups of students regarding their plens to enter college; 65.3 por cent of the non-working and 60.5 per cent of working students iricated this intention.

5) Norking students were more inclined to be settled upon a vocational choice for the future than were the non-working group; 46.8 per cent of the working as compared to 38.5 per cent of the non-working.

6) Working students were nuch nore inclined to foel that parttime work was of educational value than nero the non-working as was indicated by the fact that 90.4 per cent and 74.1 per cent, respectively indicated this cuniction.

7) Both working and non-working students felt that the schocl should do more in the way of vocational guidance ( 88 per cent of the working - 82 per cent of the non-working.) 
8) Moro than half of each group felt that vocational guidance was equal in importance to the traditional subjects offered (62 per-cent of the wcrking and 51.2 per cent of the non-working.)

9) The two groups agreed that a part-time job piacement service for high school students was a much needed and highly desirable organization (92.5 per cent of the working and 89.9 per cent of the non-working). 10) Working and non-working students alike spend their money for such things as revreation and fun, necessities, bank accounts, and gifts to church and to cherities.

To the writer, the foregoing conclusions indicate that the parttime working studgent at Loudsvill Male High School does not present a serious problem to the school. Scholastic attainment does not neem to have been seriously affected in an adverse way by participation in part-time work--in fact, according to the statements of a large per cent of the working students, such participation may have had a desirable effect upon the student's interest in school; exploitation of workers was found to be practically negligible; and although work-experience should be a part of the curriculum, the school has not been faced, in a sericus was, with the problem of altering the curriculum to accomodate the demends of either students or employers.

The problems presented to the school by pert-time working students, however, were not the primary concern of this study; determination of the noeds of high school youth and the extent to which the sheool might fulfill these noeds was the desired result. Results obtained by this study indicate some areas of need which, in the opinion of the writer, might be fulfilled by the school through some sort of organized work-experience program. These areas of need involve such aspects as placement, vocational guidance, supervisicn, anu curriculum adjustment. 
Relative to these aspects, the writer submits some recomendations which he thinks would be valuable in aiding the students at Niale High school to "bridge the gap between school and employment" and in providing "indoctrination in the democratic way of life".

In offering these recommendations, the writer omphasizes his profound respect for a well-organized and functioning curriculum touisville Male High School. He realizes, also, the difficulty which a school of this type would enounter in preparing students for college while, at the same time, operating an elaborate work-experience program - a difficulty which was found to exist in most of the schools of this included in the study of Wartime Work-Experience Programs by the National Child Labor Committee. In commenting upon this cundition, the Comittee, in tis report, says: ${ }^{1}$

Although many educators believe that work-experience is desirable for ll secondary students, fow students in college preparatory courses were found in the programs studied, and school personnel did not believe work experience could be included in the college preparatory program until college entrance requirements are made more flexible. work-study programs can help to make our work togetrer in them, and this value may be lost if trey re limited to students who lack the mental aptitude or the financial resources ficr a college education.

With these difficulties in mind, then, and upon the basis of the findings in this survey, the writer respectfully submits the followin recommendations for consideration and which he feels, also, that the aspects recommended would, in a more complete way, satisfy the needs of the students in this school.

\section{A. Placement}

Placement was found to be "one of the most importent factors in a work-experience program"2 in the survoy made by the National Child

L. Elicker, loc. cit., p. 25 .

2. Elicker, $\overline{\text { loc. }}$ cjt., pp. 18-19. 
Labor Committee because students "who found their own jobsrr..had less satisfactory working conditions than those in jobs to which they had been referred by the school". Based upon this fact and the fact that one of the most important reasons given by the non-working students at

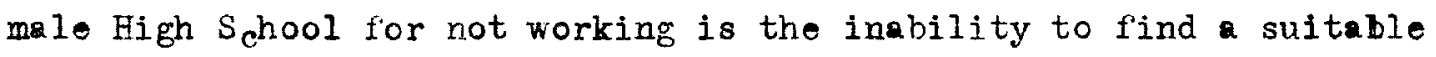
job (together with the expressed need of approximately 90 per cent of both non-working and working students for some sort of placement service for high school students), the writer rocommends that full-time placement service be organized which would insure the following:

1) Placement of students on jobs with respect to their interests and abilities, educational value of the job, and the healthfulness and safety of the working conditions

2) Rogulation of participation of students in part-time work with respect to their interest in and reason for working, their need for it, their physical fitness for work; and the possibility of their roally profiting form it

3) Placement in accordance with child labor laws and in cooperation with organized labor.

Such a placement service should be organized in cooperation with industry and business or with those employers who would be interested in supplying jobs of an educational nature to high school students. This service should soek to satisfy, as far as possible, the requests of employers and the desires of the students; thereby insuring the recommendation of only those students who were qualified by interest, ability, aptitude, and desire to satisfy the requirenents of the employer.

\section{B. Vocational Guidance}

Since over 80 per cent of both working and non-working students indicsted a feeling tret the school should do more in the way of 
vocational guidance, and since over 50 per-cent of both groups felt that vocational guidance is oqual in importance to the traditional subjeots offered by the school, the writer recommends that further investigation be made concerning this aspect to determine whother this is a real need and, if so the most efficient metrod of satisfying it.

\section{Supervision}

Supervision is also very important factor in properly functioning, work-experience progrem. The writer would, therefore, recommend for Male High School a full-time coordinator of workexperiences who would maintain "A close relationship between the employer, the school, and the student". I The coordinator would be a man of pleasing personality, energy, and possessing qualities of loadership. Fe should be traind in vocational guidance and possess a thorough knowledge of jobs and job-classification as well as having had work-experience in industry or outside the field of education. His responsibilities would include largely the vocational guidance program, the placement service, and the duties of supervision of students o $n$ part-time jobs. He should bo a spocial member of the faculty, not a rogular faculty member who acts as coordinator as a collateral duty.

\section{Curriculum Adjustment}

To make the work-experience of part-time working students at Male High School more meaningful and educational, the writer would recomend that the school investigate the possibility of including work-experience as vital part of the curriaulum. This would involve the scheduling of classes and work and possibly the allowing of credit toward graduation for truly educational work-experiences. In meling this recomendation,

I. Elicker, loc. cit., p. 30 . 
the writer is fully aware of the difficulties associated with it; and, if it were carried out, it would be necessary to evaluate all work-experience with diligence to prevent unnecessary scheduling or the granting of credit for unrelated work-experiences toward graduation. Finally, in conclusion, the writer reiterates his conviction that it is possible for part-time work exrerience to become, under the auspices of the school and with the cooperation of the comrunity, an invaluable service to the high school youth of America in aiding them to find their proper place in the life of the comruntiy and at the same time provide the commity with mor e mature, experienced, and satisfied citizens upon their advent into adult life.

The foregoing conclusions and recommendations made as the result of the findings of A Comparative Study of Part-Time and Non-Working Students at Lousvillo Male High School represent the writer's sincerest convictions, and he hopes thet they will by no means be c nsidered maliciously critical of the present curriculum practices of that school. He hopes, also, that the information and dat compiled in foregoing chapters may prove useful to that school in future curriculum development. 
APPENDIX I

QUESTIONNAIRE USED IN THIS STUDY

NAME

\begin{tabular}{cc}
\hline Last & First \\
& SCHOOL GRADE \\
\hline
\end{tabular}

PHONE NUMBER

NAME OF PARENT OR GUARDIAN

Please read each of the following questions very carefully and

then answer them to the very best of your knowledge.

1. What is your approximate averago grade standing since you have boen in high school? ( A B C D E ) (Circle appropriate one)

2. Do you plan to go to collego? (Yes No Undecided)

3. Do you plan to finish high school? (Yes No Undocidod)

4. Do you, at the prosent time, have a part-time job either after school, on the weokends, or both? (Yes No Undecided)

5. Have you decided upon your future career? (Yos No Undocidod)

6. Please answer each of the following questions by encircling one of the statements provided in parenthesis at the end of each question.

A. Do you think that a part-time job has any educational value for high school students? (Yos No Undecided)

B. Would a part-time placement (Employment) bureau whore high school students could apply for part-time work and be placed on jobs according to their interests, abilitios, otc. be a worthwhile organization? (Yos No Undecided)

C. Do you think that the school should do more to educate its students concerning the nature of various occupations, and professions in order that the student might choose his career more wisely? (Yos No Undecided)

D. Do you think that the duty of the 8 chool as mentioned in question " $\mathrm{C}$ " is as important as educating the student in subjeot natter suoh as English, Mathematics, Languages, etc ? (Yes No Undecidod)

7. FOR THOSE WHO DO HAVE A PART-TIME JOB

If you do have a part-time job please answer each of the following questions to the very best of your knowledge.

A. Where do you work?

B. What is the business of your employer?

C. What sort of work are you doing? 
D. Approximately how many hours per week do work at this part-timo job?

E. What is your approximate salary per weok?

F. Do you think that you would like to make this type work or businosa your caroer? (Yes No Undecided)

G. Do you think that your job has caused you to take moro interest in your school work and in securing on oducation? (Yes No Undecided )

H. Do you think that your job has hendered your school work in any way? (Yos No Undecided)

I. Are you being excused from part of your school day to work at this part-time job? (Yos No)

J. Does the school know that you are working part-time? (Yes No Undecided )

K. Do you like the work you are doing? (Yos No Not Especielly)

L. Why are you working? Below are three statoments as to why you might be working. In the box at the left of each place a numbor $(1,2,3$, etc. ) as to their importance in your case.

(Lit " 1 " indicate the most important). Loave blank any which do not apply. Add at the bottom any other reason you may have and rate it also.

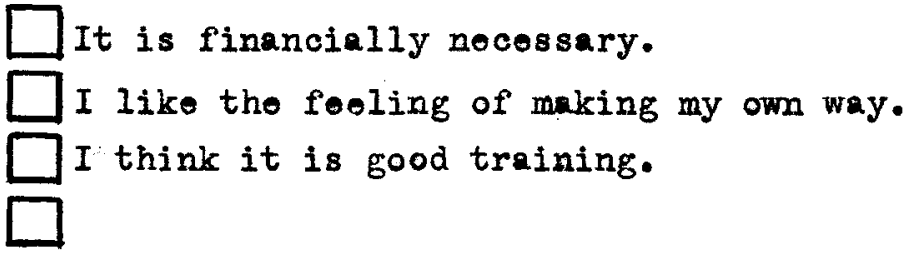

8. FOR THOSE WHO DO NOT HAVE A PART-TIME JOB

If you do not havd a part-time job please answer the following questions as accuratoly as possible.

A. Do you think it is wise for high school students to attempt to do part-time work? (Yes No Undecided)

B. Would you like to have a part-time job if you could fine one that suited you? (Yes No Undecided)

c. Why do you not have a part-time job? Below are several reasons is to why you may not be working. In the box provided at the left of each statement place a number $(1,2,3$, etc. ) as to their importance in your case. (Let "I" indicato the most important). Leave blank any which does not apply. Add at the bottom any other roason which you may have and rate it also.

Wy hoalth will not pormit it. I need all my time for my school work.

Financially it is not necessary. I can not find a job that suits me. My parents will not pormit it. 
9. WHAT DO YOU DO WITH YOUR INCOME?

This question is for everyono regardless of whether your income is a salary for part-time work or an allowance.

Please place a check in the bex provided at the left of each statement which applies to you. You may add any other statement not listed at the bottom.

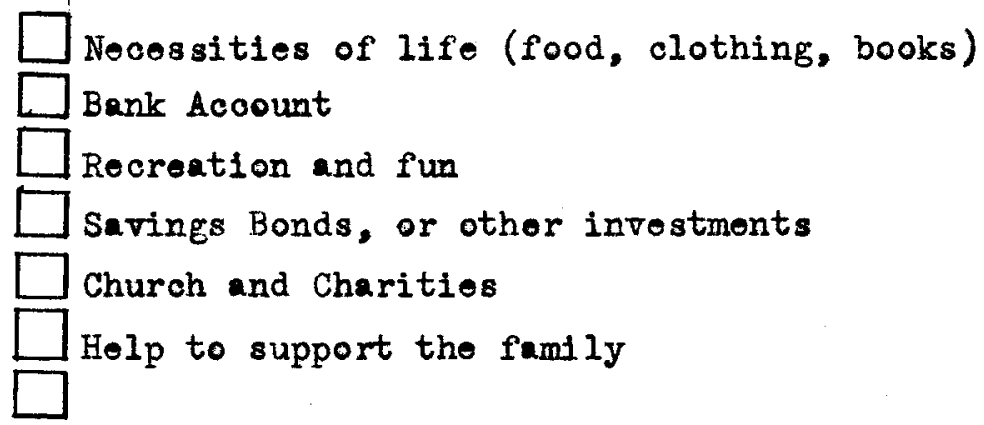

10. Have you answered all questions seriously and to the best of your ability? (Yes No ) 


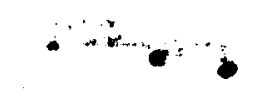

APPENDIX II

VORK PERMTT USED AT MALE HIGH SCHOOL

LOUISVILLE LiALE HIGH SCHOOL
Employment Record


BOOKS:

Bell, Howard M., Matching Youth and Jobs, Washington, D.C.: American Council on Education, 1940.

Brewer, John M., History of Vocational Guidance, New York: Harper and Brothers, 1942 .

Childs, John L., Education and the Philosophy of Experimentalism, Now York: The century Company, 1931 (c).

David, Paul T., Postwar Youth and Employment, Washington, D.C.: American Council on Education, 1943.

David, Paul T., Barriers to Youth Employment, Washington, D.C.: American Council on Education, 1942.

Eokert, Ruth E., When Youth Leave Sohool, New York: MoGraw-Hill Book Co., Inc., $19 \overline{938 .}$

Fisher, Dorothy Canfield, Our Young Folks, Now York: Harcourt, Brace and Company, 1943.

Garrett, Henry E., Statistics in Psychology and Education, New York: Longman's, Green and Company, Ino., 1926.

Good, Carter V., Barr, A.S., and Scatos, D.E., The Methodology of Eduoational Research, New York: D. Appolton-Century Co., Inc., 1935 (c).

Myors, George E., Principals and Technigues of Vocational Guidance, New York: MeGraw-Hill Book Co., Inc., 1941.

National Association of Secondery-School Prinoipals, Planning for American Youth, Washington, D.C.: National Association of Secondary-School Principals, 1944 (c).

New York State Counselors Association, Practical Handbook for Counselors, Chicago: Science Research Asseciation, 1946.

Nortion, Thomas L., Education for Work, Now York: McGraw-Hill Book Co., Inc., 1938.

Rainoy, Homer P., How Fare Amorican Youth, New York: Appelton-Century Company, 1937 .

Fakestraw, C. E., Training High-School Youth for Fimployment, Chicago: American Toohnical Sooiety, 1947. 
Doane, Donald C., The Needs of Youth, New Yerk: Bureau of Publications, Teachers College, Columbia University, 1942.

Threlkeld, Hilda, The Educational and Vocational Plans of College Sentors, New York: Bureau of Publications, Teachers Collego, Columbia University, 1935.

\section{BULLETINS AND PAMPHLETS:}

U.S. Office of Education, Federal Security Agency, Office of Education, School-and-Work Programs, Bulletin 1947, Wo. 9, Woshington, D.C.: Superintendent of Documents, Government Printing Office, 1947.

U.S. Department of Labor, Division of Labor Standarda, Foderal Labor Laws and Agencies, Bulletin 1946, No. 79, Washington, D.C.: Superintendent of Documents; Government Frinting Office, 1946

Department of Industrial Relations, Kentucky Labor Laws, Frankfort, Kentucky: Department of Industrial Rolations, June 1946.

American Youth Commission, What the High Schools Ought to Teach. Washington, D.C.: American Council on Education, 1940.

Louisville Male High School, The "H" Book, 23rd Edition, Louisville: Louisville Male High School, 1947-48.

Reeves, Floyd W., and Bell, Howard M., American Youth Faces the Future; Problems in American Life Series, Unit 2, Washington, D.C.: National Council for the Social Studies, National Association of Secondary-Schools, 1942 .

\section{PERIODICALS :}

Browne, E.C., "Potersburg High School Work-Experience Program", Occupations, 25: 231 , January 1947.

Christonsen, Thomas E., "Work-Experience in the Post-Har High School", Schools and Society, 63: 51-53, January 1946.

Elicker, P.E., "Wartime Work-Experience Programs", The National Association of Secondary-School Principals - The Bulletin. $30:$ 15-31, October 1946.

Forkner, Hamden L., "Work-Experience - A Must in Education", Teachers College Record, $48: 435-439$, April 1947 . 
Gilbert, A.W., "Work-Experience for Secondary-School Pupils", The National Association of Secondury-School Principals - The Bulletin, 28: 36-40, May. 1944.

Gilchrist, R.S. and Gillies, Edith, "Imperative Need Number I", The National Association of Secondary-Sohool Principals - The Bulletin, 31: 7-25, Narch 1947.

Holtrop, W.F., "Work-Experience in the Small Secondary-School", The National Association of Secondary-School Principals - The Bulletin, 28: 59-65, January 1944.

Lancy, Edward and Others, "Occupational Adjustment and the Sohool", The National Association of Secondary-School Prinoipals - The Bulletin, 24: 145 pp., November 1940.

Loonard, J. Paul, "Work-Exporience in Secondary Education", The National Association of Secondary-School Principals - Tho Bulletin, 28: 29-35, May 1944.

Masen, John E. and Losuer, Bruce L., "A Work-Experience Program" The National Association of Secondary-School Principals - The Bulletin, 28: 51-55, November 1944.

Myers, William E., "High School Graduates Choose Vocations Charealistically", Occupations, 25: 332-333, Maroh 1944.

Sutton, Traver and Amiss, John M., "10 Questions About Work-Experionce", Clearing House, 20: 410-412, March 1944.

Weisiger, Louise P., "A Plan for the Development of School Placement Service in Richmond, Virginia for School-Leaving Youth", Journal of Educational Research, 39 : 622-231, April 1946.

Wert, James E., and Noidt, Charles 0., "Education-for-Work Movements", Reviow of Educational Rosearch, 17: 202-208, June 1947.

YEARBOOK:

American Association of School Administrators, Schools and Manpower, 2lst Yoarbook, Washington, D.C.: National Education Association, 1943 (c). 